\title{
Respon Kebijakan Covid-19: Merger BUMN Transportasi dan Pariwisata untuk Mengatasi Kontraksi Ekonomi di Masa Pandemi
}

I Dewa Gde Sugihamretha ${ }^{1}$

${ }^{1}$ Perencana Ahli Utama di Kementerian PPN/Bappenas RI

Korespondensi: gde@bappenas.go.id

\section{https://doi.org/10.47266/bwp.v4i2.103 | halaman: 138-166}

Dikirim: 20-08-2021 | Diterima: 01-09-2021 | Dipublikasikan: 20-09-2021

\begin{abstract}
Abstrak
Di era normal, industri pariwisata merupakan sektor jasa dengan tingkat pertumbuhan cukup pesat di dunia dan telah menjadi penggerak utama (key driver) kemajuan sosio-ekonomi suatu negara melalui penerimaan devisa, penciptaan lapangan pekerjaan dan kesempatan berusaha, serta pembangunan infrastruktur. Dimasa pandemi Covid-19, seluruh negara di dunia menghadapi goncangan ekonomi. Indonesia mencoba mencari solusi menghadapi krisis ekonomi, salah satu jalan keluarnya adalah menggabungkan BUMN penerbangan dan pariwisata. Transportasi sangat erat kaitannya dengan pariwisata. Hal ini nampak dari besarnya uang yang dibelanjakan wisatawan manca negara (wisman) dan wisatawan nusantara (wisnus) di Indonesia pada produk barang dan jasa yang dikonsumsi yaitu sebesar Rp. 452,43 triliun, di dalamnya termasuk pengeluaran untuk biaya transportasi sebesar Rp. 107 triliun. Pengeluaran terbesar dalam transportasi adalah untuk angkutan udara sebesar Rp. 53,3 triliun (50\%), disusul pengeluaran angkutan lainnya seperti angkutan jalan raya, sewa kendaraan, angkutan air, dan angkutan kereta api. Dalam bisnis penerbangan di Indonesia, maskapai penerbangan Garuda Indonesia hanya menguasai $46 \%$ pangsa pasar, sisanya dikendalikan oleh swasta. Tulisan ini menyajikan analisa fenomena rencana penggabungan BUMN penerbangan dan pariwisata dan memetakan kekuatan BUMN penerbangan dan peran moda transportasi lainnya dalam mendorong pergerakan wisatawan keseluruh tujuan wisata di tanah air. Selanjutnya mencoba memberikan rekomendasi strategi kebijakan penataan menyeluruh dan terintegrasi secara nasional BUMN transportasi dan pariwisata. Tulisan ini disusun dari berbagai sumber literatur dan desk study.
\end{abstract}

Kata kunci: Transportasi, Pariwisata, kebijakan pariwisata, pandemi covid-19 


\title{
Respon Kebijakan Covid-19: Merger BUMN Transportasi dan Pariwisata untuk Mengatasi Kontraksi Ekonomi di Masa Pandemi
}

\author{
I Dewa Gde Sugihamretha
}

\section{Pengantar}

Dimasa pandemi covid 19, dalam laporan berita resmi statistik 5 Agustus 2020, Ekonomi Indonesia triwulan II-2020 dibanding triwulan II-2019 mengalami kontraksi pertumbuhan sebesar 5,32 persen. Kontraksi pertumbuhan terjadi pada hampir semua lapangan usaha. Pariwisata berkonstribusi signifikan terhadap kontraksi ekonomi Indonesia. Hal ini nampak pada dua lapangan usaha yang menjadi klaster pembangunan pariwisata yaitu transportasi dan pergudangan yang mengalami kontraksi pertumbuhan 30,84 persen; dan penyediaan akomodasi dan makan minum yang mengalami kontraksi 22,02 persen.

Presiden pada saat membuka rapat terbatas (6 Agustus 2020) menyampaikan bahwa penyebab utama dari terkontraksi ekonomi Indonesia adalah sektor pariwisata. Seperti diketahui, pandemi Covid-19 telah membuat geliat sektor pariwisata dan transportasi terpuruk. Angka kunjungan wisatawan mancanegara kuartal II/2020 hanya 482.000 orang. Jumlah tersebut turun $87 \%$ dari periode yang sama tahun lalu. Presiden mengatakan bahwa penurunan ini justru menjadi momentum untuk konsolidasi, momentum untuk transformasi dengan menggabungkan BUMN di bidang penerbangan dan pariwisata agar bisa memberikan pelayanan terbaik untuk wisatawan. Perbaikan sektor pariwisata dan penerbangan perlu dilakukan menyeluruh agar pemulihan ekonomi bisa optimal.

\section{Analisis dan Pembahasan}

Transportasi mempunyai peranan yang sangat strategis untuk meningkatkan pertumbuhan ekonomi dan wilayah. Indonesia memiliki jalur darat, air maupun udara sebagai akses untuk menuju ke suatu tempat yang harus didukung dengan moda transportasi di tiga jalur tersebut. Keseluruhan penyelenggaraan transportasi perlu mengintegrasikan berbagai moda dalam suatu sistem pelayanan untuk meningkatkan kelancaran arus barang dan mobilitas orang, yang lazim disebut dengan kegiatan transportasi antarmoda/multimoda sehingga dapat menekan waktu dengan biaya lebih efisien dan pada akhirnya dapat meningkatkan nilai tambah terhadap barang dan perjalanan orang termasuk layanan untuk para wisatawan.

\subsection{Hubungan Transportasi Dan Pariwisata}

Hubungan transportasi dan pariwisata menjadi bagian fundamental, sangat penting dan vital. Transportasi adalah aktivitas yang sangat kompleks, berdampak pada semua kehidupan sehari-hari. Kita semua adalah pemangku kepentingan transportasi, terlibat dalam industri transportasi dengan berbagai cara seperti bepergian ke tempat kerja, terbang ke tempat liburan. Kebijakan transportasi tidak hanya mempengaruhi pengalaman perjalanan penduduk setempat, tetapi juga penting bagi wisatawan saat menavigasi arah perjalanan dari tiba hingga mencapai tujuan akhir mereka. 
Salah satu unsur strategis dalam aktivitas kepariwisataan adalah transportasi. Peran transportasi sangat penting dalam sistem kepariwisataan dimana transportasi membawa wisatawan dari asal wisatawan menuju daerah tujuan (Lepier dalam Cooper et al, 1993). Dalam pengembangan destinasi, Middleton dalam Marketing Tourism and Travel(2001:11) kegiatan yang terkait dengan pariwisata adalah jasa penginapan (accomodation), daya tarik wisata (attraction), transportasi (transport), Travel Organizer, dan Destination Organization. Membangun infrastruktur transportasi menjadi lebih rumit ketika mempertimbangkan perbedaan dari konteks geografis. Indonesia negara besar dan terdiri dari pulau besar dan ribuan pulau-pulau kecil sehingga satu daerah dengan daerah yang lain membutuhkan dukungan infrastruktur yg berbeda-beda. Menghubungkan pulau-pulau di Indonesia, selain transportasi udara juga membutuhkan berbagai moda transportasi lainnya.

Dwyer et.al (2000) dan Tyrrell \& Johnston (2001) menyampaikan bahwa para wisatawan sebagai konsumen menghadapi situasi yang kompleks dalam mengambil keputusan rencana perjalanan, namun mereka setuju pentingnya keterkaitan aksesibilitas transportasi dan tingkat layanan sesuai dengan trend pasar pariwisata. Davies et.al (2006) menyoroti bahwa pendorong utama pertumbuhan pariwisata di destinasi tertentu berhubungan dengan kondisi ekonomi asal dan tujuan, biaya logistik dan regulasi serta kapabilitas dan kinerja rantai pasok. Keputusan penumpang untuk memilih opsi liburan yang paling sesuai tergantung pada berbagai faktor seperti profil konsumen, jarak tujuan akhir, pilihan transportasi dan harga layanan. Pariwisata, sebagai kegiatan ekonomi, mengandalkan transportasi untuk membawa wisatawan ke destinasi dan transportasi menjadi bagian dari pengalaman berwisata seperti kapal pesiar.

\subsection{Transportasi Penerbangan}

Transportasi penerbangan adalah kontributor utama bagi kemakmuran ekonomi global. Penerbangan menyediakan satu-satunya jaringan transportasi cepat di seluruh dunia, yang menjadikannya penting untuk bisnis global. Bisnis penerbangan menghasilkan pertumbuhan ekonomi, menciptakan lapangan kerja, dan memfasilitasi perdagangan dan pariwisata internasional. Pada tahun 2016, menurut ATAG total dampak ekonomi (langsung, tidak langsung, terinduksi, dan terkait dengan pariwisata) dari industri penerbangan global mencapai USD 2,7 triliun, sekitar 3,6 persen PDB dunia. Industri transportasi udara juga menciptakan 65,5 juta pekerjaan secara global (Gambar 1). Memberikan 10,2 juta pekerjaan langsung. Maskapai penerbangan, penyedia layanan navigasi udara, dan bandara secara langsung mempekerjakan sekitar 3,5 juta orang.

Salah satu industri yang sangat bergantung pada penerbangan adalah pariwisata. Dengan memfasilitasi pariwisata, transportasi udara membantu menghasilkan pertumbuhan ekonomi dan mengentaskan kemiskinan. Saat ini, sekitar 1,4 miliar wisatawan melintasi perbatasan setiap tahun, lebih dari setengahnya melakukan perjalanan ke tujuan mereka melalui udara. Pada tahun 2016, penerbangan berkonstribusi hampir 37 juta pekerjaan di sektor pariwisata, menyumbang sekitar USD 897 miliar per tahun untuk PDB global.

Dalam situasi pandemi Covid-19 dan ketidakpastian ekonomi, Asosiasi Transportasi Udara Internasional (IATA) merilis bahwa maskapai penerbangan diperkirakan akan kehilangan \$ 84,3 miliar pada tahun 2020 dengan margin laba bersih 20,1\%. Pendapatan akan turun 50\% menjadi \$ 419 miliar dari \$ 838 miliar pada tahun 2019 . 
Secara finansial, 2020 akan menjadi tahun terburuk dalam sejarah penerbangan. Rata-rata, setiap hari dalam tahun ini akan menambah \$ 230 juta untuk kerugian industri. Total kerugiannya \$ 84,3 miliar. Artinya, berdasarkan perkiraan 2,2 miliar penumpang tahun ini, maskapai penerbangan akan kehilangan \$37,54 per penumpang. Terpuruknya bisnis penerbangan membutuhkan bantuan keuangan pemerintah.

65.5 million

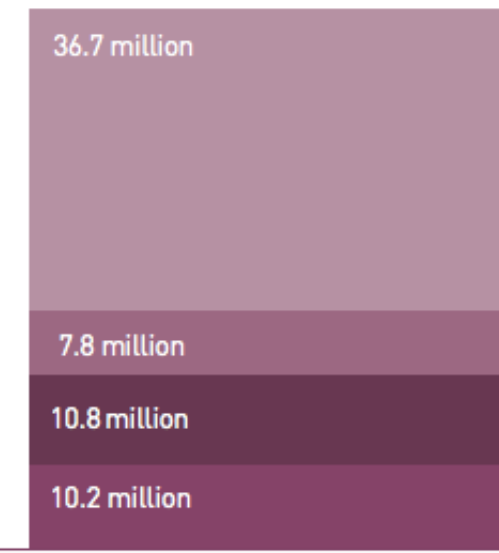

EMPLOYMENT [JOBS]
$\$ 2.7$ trillion

Tourism catalytic

Induced

$\$ 454.0$ billion

$\$ 637.8$ billion

Indirect

\section{$\$ 704.4$ billion}

Gambar 1. Ketenagakerjaan penerbangan global dan dampak PDB-nya.

Pada tahun 2021, kerugian diperkirakan akan berkurang menjadi \$ 15,8 miliar karena pendapatan meningkat menjadi \$ 598 miliar. Asalkan tidak ada gelombang kedua yang lebih merusak dari Covid-19, kehancuran bisnis penerbangan yang terburuk kemungkinan besar sudah berlalu. Kunci pemulihannya adalah implementasi universal dari langkah-langkah memulai kembali yang disepakati melalui Organisasi Penerbangan Sipil Internasional (ICAO) untuk menjaga keselamatan penumpang dan awak. Dengan bantuan pelacakan kontak yang efektif, langkah-langkah ini harus memberikan kepercayaan kepada pemerintah untuk membuka perbatasan tanpa tindakan karantina. Itu adalah bagian penting dari pemulihan ekonomi karena sekitar 10\% dari PDB dunia berasal dari pariwisata dan sebagian besar bergantung pada perjalanan udara. Membuat orang terbang kembali dengan aman akan menjadi pendorong ekonomi yang kuat.

\subsection{Daya Saing Indonesia}

Peringkat daya saing Indonesia dalam laporan Global Competitiveness Index (GCI) 2019 yang baru dirilis World Economic Forum (WEF) turun ke posisi 50 dari posisi 45 pada tahun lalu (Tabel: 1). Tak hanya penurunan peringkat, skor daya saing Indonesia juga turun meski tipis 0,3 poin ke posisi 64,6. Berdasarkan daftar tersebut, Indonesia makin tertinggal jauh dari Singapura yang menempati posisi pertama. Demikian pula dari Malaysia dan Thailand yang sebenarnya juga turun masing-masing dua peringkat tetapi mash diposisi 27 dan 40. WEF dalam laporannya menyebut skor daya saing Indonesia sebenarnya tak banyak berubah. Lembaga itu juga menilai Indonesia memiliki kekuatan pada pasar dan stabilitas makro ekonomi. Meski demikian, peringkat Indonesia terkait stabilitas makro turun dari sebelumnya 51 menjadi ke peringkat 54 . Pembangunan infrastruktur yang masif juga belum 
berhasil mengangkat peringkat daya saing Indonesia, terkait infrastruktur justru turun tahun ini dari posisi 71 tahun lalu menjadi 72 .

Tabel 1. Global competitive Index 2019

\begin{tabular}{|c|c|c|c|c|c|c|c|c|}
\hline \multirow[b]{2}{*}{ Economy } & \multirow[b]{2}{*}{ Score ${ }^{1}$} & \multicolumn{2}{|c|}{ Diff. from $2018^{2}$} & \multirow[b]{2}{*}{ Rank } & \multirow[b]{2}{*}{ Economy } & \multirow[b]{2}{*}{ Score' } & \multicolumn{2}{|c|}{ Diff. from $2018^{2}$} \\
\hline & & Rank & Score & & & & Rank & Score \\
\hline Singapore & 84.8 & +1 & +1.3 & 48 & Mexico & 64.9 & -2 & +0.3 \\
\hline United States & 83.7 & -1 & -2.0 & 49 & Bulgaria & 64.9 & +2 & +1.3 \\
\hline Hong Kong SAR & 83.1 & +4 & +0.9 & 50 & Indonesia & 64.6 & -5 & -0.3 \\
\hline Netherlands & 82.4 & +2 & - & 51 & Romania & 64.4 & +1 & +0.9 \\
\hline Switzerland & 82.3 & -1 & -0.3 & 0 & Mauritius & 64.3 & -3 & +0.5 \\
\hline
\end{tabular}

\section{Indonesia}

\begin{tabular}{|c|c|c|c|}
\hline Index Component & Value & Score ${ }^{*}$ & Rank/141 \\
\hline . 2nd pillar: Infrastructure $0-100$ & - & $67.7 \uparrow$ & 72 \\
\hline Transport infrastructure $0-100$ & - & $56.1 \uparrow$ & 55 \\
\hline 2.01 Road connectivity $0-100$ (best) & 59.8 & $59.8 \uparrow$ & 109 \\
\hline 2.02 Quality of road infrastructure 1-7 (best) & 4.2 & $52.6 \uparrow$ & 60 \\
\hline 2.03 Railroad density $\mathrm{km} / 1,000 \mathrm{~km}[\mathrm{l} 2$ & 2.6 & $6.5 \uparrow$ & 85 \\
\hline 2.04 Efficiency of train services 1-7 (best) & 4.7 & $61.1 \downarrow$ & 19 \\
\hline 2.05 Airport connectivity score & $972,336.6$ & $100.0=$ & 5 \\
\hline 2.06 Efficiency of air transport services 1-7 (best) & 4.9 & $65.2 \downarrow$ & 56 \\
\hline 2.07 Liner shipping connectivity 0-100 (best) & 47.8 & $47.8 \uparrow$ & 36 \\
\hline 2.08 Efficiency of seaport services 1-7 (best) & 4.3 & $55.8+$ & 61 \\
\hline Utility infrastructure $0-100$ & - & $79.4 \downarrow$ & 89 \\
\hline 2.09 Electricity access \% of population & 94.8 & $94.8 \uparrow$ & 95 \\
\hline 2.10 Electricity supply quality \% of outpu: & 9.1 & $94.7 \uparrow$ & 54 \\
\hline 2.11 Exposure to unsafe drinking water $\%$ of population & 35.8 & $65.5 \downarrow$ & 98 \\
\hline 2.12 Reliability of water supply 1-7 (best) & 4.8 & $62.5 \uparrow$ & 74 \\
\hline 해 3rd pillar: ICT adoption 0-100 & - & $55.4 \downarrow$ & 72 \\
\hline 3.01 Mobile-cellular telephone subscriptions per 100 pop. & 119.8 & $99.9 \downarrow$ & 64 \\
\hline 3.02 Mobile-broadband subscriptions per 100 pop. & 87.2 & N/Appl. & 52 \\
\hline 3.03 Fixed-broadband Internet subscriptions per 100 pop. & 3.3 & $6.6 \uparrow$ & 97 \\
\hline 3.04 Fibre internet subscriptions per 100 pop. & 1.5 & N/Appl. & 63 \\
\hline 3.05 Internet users $\%$ of adult population & 39.8 & $39.8+$ & 104 \\
\hline
\end{tabular}

Sumber: WEF, GCI 2019

Daya Saing Logistik dan Pariwisata Indonesia. Berbagai kalangan praktisi di bidang logistik memandang, transportasi antarmoda/multimoda merupakan bagian integral yang tidak terpisah dengan sistem logistik transportasi antarmoda/multimoda dalam sistem logistik berfungsi merencanakan, melaksanakan dan mengontrol proses penerimaan, pengemasan, penyimpanan barang, pelayanan informasi, mulai dari titik awal (point of origin) sampai di titik akhir tujuan barang untuk diterima oleh orang yang berhak.

Dilihat dari peringkat Logistics Performance Index (LPI) dari Bank Dunia, Indonesia berada pada posisi 53 di tahun 2014, 63 di 2016, dan 46 di 2018. Walaupun peringkatnya 
meningkat pada 2018, namun peringkat LPI Indonesia di antara negara-negara ASEAN mengalami penurunan dari posisi ke-4 menjadi posisi ke-5 di bawah Singapore (peringkat 7), Thailand (32), Vietnam (39), dan Malaysia (41). Hal ini mengindikasikan kinerja sektor logistik di negara-negara ASEAN lainnya itu meningkat lebih baik daripada Indonesia. Penyelenggaraan transportasi ditata dalam satu kesatuan jaringan transportasi nasional untuk meningkatkan kalancaran arus barang dan mobillitas orang termasuk salah satunya adalah bidang pariwisata.

Daya saing pembangunan pariwisata. Daya saing pariwisata Indonesia meningkat ke peringkat 40 pada 2019 dari 42 pada tahun sebelumnya (WEF, The Travel \& Tourism Competitiveness Report 2019). Indonesia meraih skor 4,3 dari total penilaian pilar-pilar dari yg terbaik sampai yang terburuk seperti daya saing harga $(6,1)$, keamanan $(5,4)$, sumber daya manusia dan lapangan kerja $(4,9)$, lingkungan bisnis $(4,7)$, kesehatan dan kebersihan (4,5), keberlanjutan lingkungan $(3,5)$, infrastruktur dan layanan pariwisata $(3,1)$. Di kawasan Asia Tenggara, indeks daya saing pariwisata Indonesia berada di peringkat empat. Posisi Indonesia masih tertinggal dibandingkan Singapura, Malaysia, dan Thailand. Ketiga negara tetangga tersebut masing-masing berada di peringkat 17, 29, dan 31 dunia.

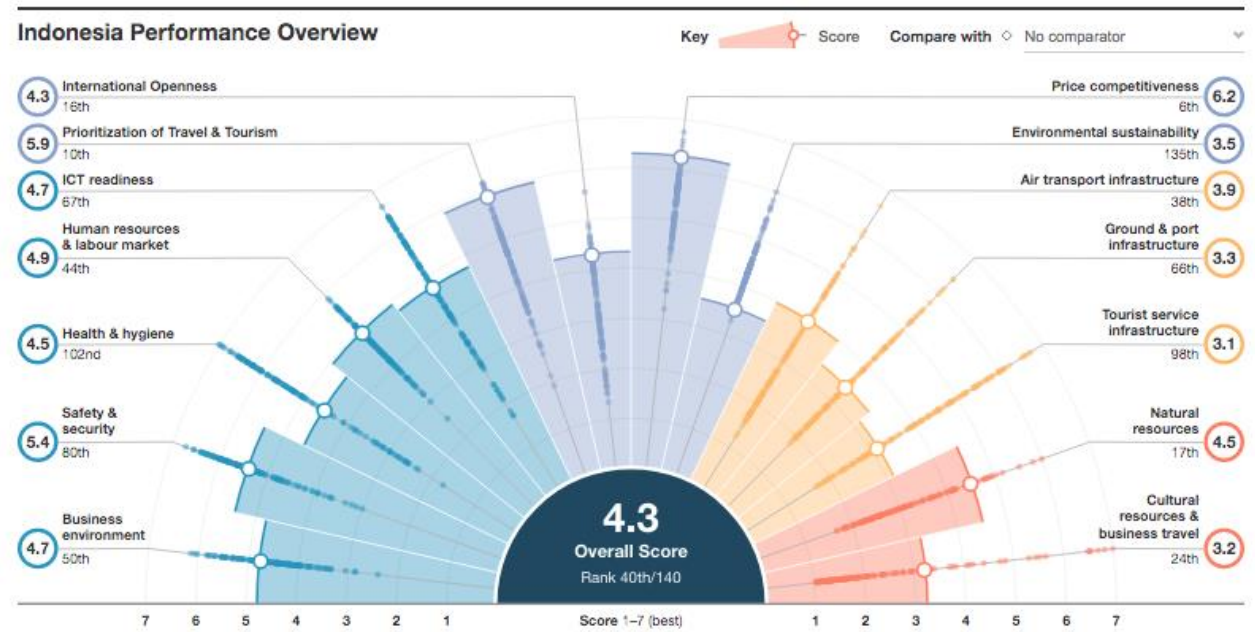

Gambar 2: Daya Saing Pariwisata Indonesia

Sumber: WEF, TTCI 2019 Report.

Hadirnya transportasi tidak hanya menunjang kebutuhan masyarakat dalam kesehariannya namun juga menunjang kegiatan pariwisata dan penyedia jasa wisata. Dalam pariwisata ada 3 elemen penting untuk pengembangan pariwisata yaitu atraksi, amenitas dan aksesibilitas. Dalam aksesibilitas inilah sarana dan prasarana transportasi merupakan salah satu yang terpenting dalam menunjang kegiatan dan pengembangan pariwisata. Destinasidestinasi wisata di Indonesia masih banyak yang belum dijangkau oleh akses transportasi umum. Maka pilihan wisatawan adalah menggunakan jasa wisata swasta seperti sewa mobil/sepeda motor untuk menjangkau destinasi yang ingin dituju. Pada tahun 2017, wisman dan wisnus mengeluarkan biaya transportasi sebesar Rp. 11,5 triliun untuk sewa kendaraan.

2.4. Pengeluaran Wisatawan 
Dilihat dari besarnya uang yang dibelanjakan wisman selama mengunjungi Indonesia, pada tahun 2017 total konsumsi wisman di Indonesia mencapai Rp 198,89 triliun (Tabel: 2). Jika dibandingkan dengan nilai konsumsi wisman pada tahun 2016 yang sebesar Rp 176,23 triliun, konsumsi wisman tahun 2017 mengalami peningkatan (12,86 persen). Pengeluaran wisman selama di Indonesia terbesar adalah untuk membayar jasa hotel atau akomodasi lainnya dan produk makanan dan minuman masing-masing mencapai 40,14 persen dan 18,14 persen dari total pengeluaran. Pengeluaran lain yang cukup besar adalah untuk biaya transportasi yang meliputi angkutan rel, jalan raya, air, udara dan penyewaan kendaraan yang mencapai 18,0 persen. Pengeluaran untuk membeli cinderamata juga cukup besar, yaitu mencapai 6,26 persen.

Tabel 2. Struktur Pengeluaran Wisman Menurut Produk Barang dan Jasa yang

Dikonsumsi Tahun 2017

\begin{tabular}{ccc} 
Produk & $\begin{array}{c}\text { Nilai } \\
\text { (miliar rupiah) }\end{array}$ & $\begin{array}{c}\text { Distribusi } \\
\text { (\%) }\end{array}$ \\
\hline$(1)$ & $(2)$ & $(3)$ \\
\hline
\end{tabular}

A. Produk karakteristik pariwisata

1. Akomodasi dan sejenisnya

$79827,4 \quad 40,14$

2. Makanan dan minuman

36085,0

18,14

3. Angkutan KA

$1134,0 \quad 0,57$

4. Angkutan jalan raya

14578,9

0,57

5. Angkutan air

2429,0

7,33

6. Angkutan udara

17343,2

1,22

7. Sewa kendaraan

324,0

8,72

8. Agen perjalanan dan jasa

3319,0

0,16 reservasi

9. Pertunjukan seni, budaya,

$1031,2 \quad 0,52$
museum dan peninggalan sejarah

10. Jasa rekreasi/hiburan

9281,0

4,67

11. Cinderamata

12457,6

6,26

12. Kecantikan dan kesehatan

4477,0

2,25

13. Pertemuan, seminar, konferensi

1106,3

0,56

B. Produk konsumsi lainnya

14. Belanja

15. Bahan bakar dan pelumas

13798,0

6,94

16. Lainnya

1700,1

0,85

\begin{tabular}{crr}
\hline Jumlah & 198891,6 & 100,00
\end{tabular}


Tabel 3. Struktur Pengeluaran Wisnus Menurut Produk Barang dan Jasa yang Dikonsumsi Tahun 2017

\begin{tabular}{ccc} 
Jenis Produk & $\begin{array}{c}\text { Nilai } \\
\text { (miliar rupiah) }\end{array}$ & $\begin{array}{c}\text { Distribusi } \\
(\%)\end{array}$ \\
\hline$(1)$ & $(2)$ & $(3)$ \\
\hline
\end{tabular}

A. Produk Karakteristik Pariwisata

1. Akomodasi dan sejenisnya

2. Makanan dan minuman

3. Angkutan KA

4. Angkutan jalan raya

5. Angkutan air

6. Angkutan udara

7. Sewa kendaraan

8. Agen perjalanan dan jasa reservasi

9. Pertunjukan seni, budaya, museum dan peninggalan sejarah

10. Jasa rekreasi/hiburan

11. Cinderamata

12. Kecantikan dan kesehatan

13. Pertemuan, seminar, konferensi

$\begin{array}{rr}16290,97 & 6,43 \\ 76545,38 & 30,20 \\ 2439,77 & 0,96 \\ 17207,36 & 6,79 \\ 6350,40 & 2,51 \\ 36021,61 & 14,21 \\ 11177,55 & 4,41 \\ 1665,77 & 0,66 \\ 901,69 & 0,36 \\ 6331,49 & 2,50 \\ 11844,49 & 4,67 \\ 7933,93 & 3,13 \\ 741,60 & 0,29\end{array}$

\section{B. Produk konsumsi lainnya}

\begin{tabular}{|c|c|c|}
\hline 14. Belanja & 42274,73 & 16,68 \\
\hline 15. Bahan bakar dan pelumas & 11573,38 & 4,57 \\
\hline 16. Lainnya & 4174,21 & 1,65 \\
\hline Total Pengeluaran & 253474,34 & 100,00 \\
\hline
\end{tabular}

Sumber: BPS

Perjalanan wisnus ke suatu daerah akan menstimulasi pertumbuhan ekonomi di daerah tersebut, sehingga perjalanan wisnus selain ikut memperkenalkan budaya daerah kepada wisatawan, juga bisa merupakan sarana pemerataan pendapatan antar daerah. Dari 270,82 juta perjalanan wisnus pada tahun 2017, jumlah pengeluaran konsumsinya mencapai Rp 253,47 triliun atau rata-rata pengeluaran per perjalanan mencapai Rp 935,54 ribu (Tabel: 3). Bagian terbesar pengeluaran ini digunakan untuk makanan dan minuman, yaitu 30,20 persen, sementara pengeluaran untuk akomodasi hanya mencapai 6,43 persen. Ini menunjukkan bahwa penduduk Indonesia yang melakukan perjalanan domestik banyak yang tidak menggunakan jasa akomodasi komersial. Hal ini dapat dipahami karena sebagian besar perjalanan wisnus tujuan utamanya adalah mengunjungi keluarga atau saudara. Sementara pengeluaran untuk angkutan yang meliputi angkutan kereta api, jalan raya, air, udara, dan sewa kendaraan mencapai 28,88 persen. Angkutan udara mempunyai persentase terbesar mencapai 14,21 persen, diikuti angkutan jalan raya dan sewa kendaraan yang masing-masing 6,79 persen dan 4,41 persen. Sementara yang terkecil adalah untuk angkutan kereta api yang hanya sebesar 0,96 persen. 
Tabel 4. Struktur Pengeluaran Wisman dan Wisnus Untuk Biaya Transportasi Tahun 2017

\begin{tabular}{|c|c|c|c|c|c|c|}
\hline \multirow[b]{2}{*}{ Jenis Angkutan } & \multicolumn{2}{|l|}{ Wisman } & \multicolumn{2}{|l|}{ Wisman } & \multirow[t]{2}{*}{ Jumlah } & \multirow[t]{2}{*}{$\%$} \\
\hline & $\begin{array}{c}\text { Nilai } \\
\text { (Miliar Rupiah) }\end{array}$ & $\%$ & $\begin{array}{c}\text { Nilai } \\
\text { (Miliar Rupiah) }\end{array}$ & $\%$ & & \\
\hline Angkutan KA & $1,134.0$ & 0.03 & $2,439.8$ & 0.03 & $3,573.8$ & 0.03 \\
\hline Angkutan Jalan Raya & $14,587.9$ & 0.43 & $17,207.4$ & 0.24 & $31,795.3$ & 0.30 \\
\hline Angkutan Air & 429.0 & 0.01 & $6,350.4$ & 0.09 & $6,779.4$ & 0.06 \\
\hline Angkutan Udara & $17,343.2$ & 0.51 & $36,021.6$ & 0.49 & $53,364.8$ & 0.50 \\
\hline \multirow[t]{2}{*}{ Sewa Kendaraan } & 324.0 & 0.01 & $11,177.6$ & 0.15 & $11,501.6$ & 0.11 \\
\hline & $33,818.1$ & 1.0 & $73,196.7$ & 1.0 & $107,014.8$ & 1.0 \\
\hline
\end{tabular}

Sumber: Diolah Oleh IDGS dari Nesparnas 2017

Keseluruhan pengeluaran wisman dan wisnus untuk biaya transportasi adalah sebesar Rp. 107 triliun, pengeluaran terbesar untuk angkutan udara Rp. 53,3 triliun (50\%), disusul pengeluaran untuk angkutan jalan raya Rp. 31 triliun (30\%), sewa kendaraan Rp. 11,5 triliun, angkutan air Rp. 6,7 triliun, dan Rp. 3,5 triliun untuk angkutan kereta api (Tabel: 4).

\subsection{BUMN Penerbangan dan Pariwisata}

Wabah virus corona (Covid-19) berdampak besar terhadap industri penerbangan di dunia, termasuk di Indonesia. Jumlah penerbangan merosot tajam dari puluhan ribu penerbangan menjadi hanya puluhan saja. Menteri Keuangan dalam Rapat Kerja bersama Badan Anggaran Dewan Perwakilan Rakyat 4 Mei 2020 mengatakan bahwa dari 79 ribu penerbangan di Indonesia sekarang tinggal 70 penerbangan, 12.703 penerbangan domestik dan internasional di 15 bandara Indonesia dibatalkan sepanjang Januari-Februari. Sektor layanan udara pun kehilangan pendapatan hingga Rp 207 miliar selama periode tersebut. Namun Menteri Keuangan juga menegaskan bahwa hal ini terjadi di seluruh dunia. Pasalnya, ada sekitar 240 ribu penerbangan yang dibatalkan di seluruh dunia pada periode 23 Januari - 18 Februari 2020. Potensi pendapatan yang hilang tahun ini pun diperkirakan mencapai US\$314 miliar atau lebih dari Rp 4.700 triliun

Dalam bisnis penerbangan di Indonesia, perusahaan BUMN Garuda Indonesia hanya memegang $46 \%$ pangsa pasar, terbesar kedua, setelah mengambil alih pengelolaan operasional Sriwijaya Air dan NAM Air. Hal tersebut diwujudkan dengan kerja sama operasi (KSO) antara Citilink dengan Sriwijaya. Lion Air Group penguasaan pangsa pasar sebesar $50 \%$. Adapun Indonesia Air Asia hanya memiliki pangsa pasar sebesar 2\% (Gambar: 3). 
60

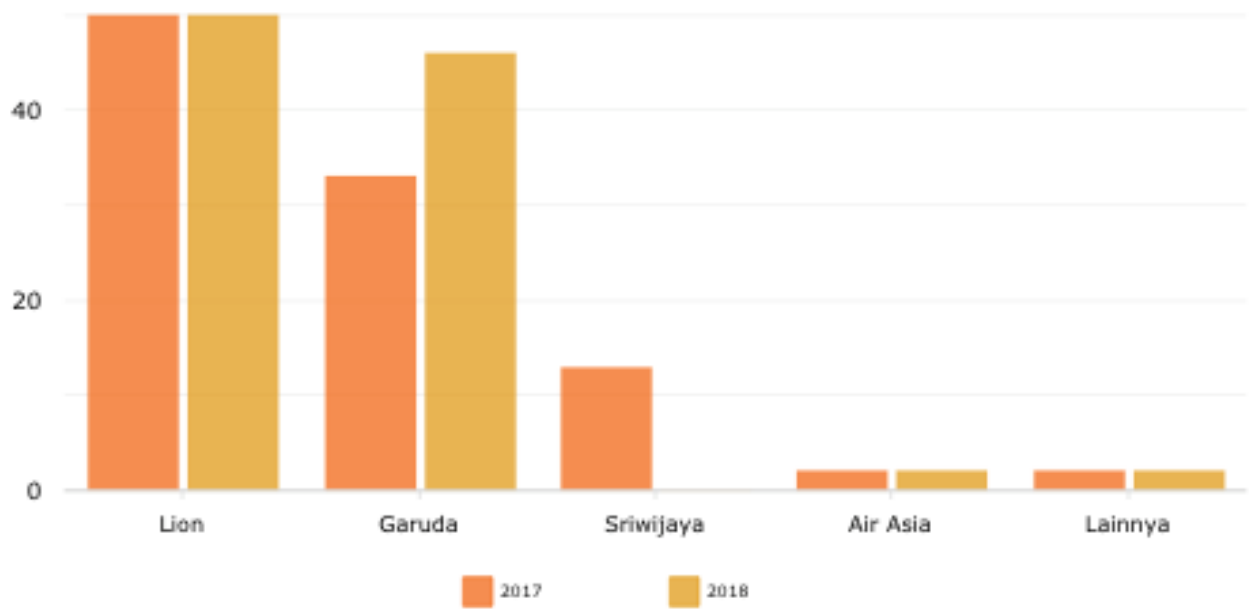

Gambar 3: Perkembangan Pangsa Pasar Maskapai Domestik 2017 dan 2018 Sumber : Katadata, Centre for Aviation (CAPA), Institute for Development Economy and Finance (INDEF) .

Sinergi BUMN pariwisata ke dalam holding melibatkan PT Taman Wisata Candi Borobudur, Prambanan dan Ratu Boko, PT Pengembangan Pariwisata Indonesia (ITDC), PT. Hotel Indonesia Natour,PT. Patra Jasa (anak perusahaan Pertamina), dan PT. Aero Wisata (Garuda Indonesia).

\section{Identifikasi Permasalahan}

Wilayah Jawa-Bali menjadi barometer perekonomian Indonesia. Jika aktivitas perekonomian di Jawa dan Bali mengalami penurunan maka dipastikan akan berdampak terhadap perekonomian nasional. Begitu halnya dengan keberhasilan implementasi strategi transformasi ekonomi yang diarahkan untuk menurunkan ketergantungan ekonomi terhadap sumber daya alam (SDA) ke arah industri manufaktur dan jasa yang berdaya saing dan bernilai tambah tinggi, juga akan tergantung kepada keberhasilan dalam melakukan transformasi ekonomi di Wilayah Jawa dan Bali. Apakah selama ini kebijakan-kebijakan ekonomi telah diarahkan untuk memperkuat fondasi utama pada sektor industri manufaktur dan Jasa? Sejauhmana kinerja sektor-sektor penting yang diharapkan akan mampu menjadi pemicu utama dalam dalam melakukan transformasi ekonomi? Apa kebijakan yang semestinya dilakukan yang dapat mendorong keberhasilan kebijakan transformasi ekonomi untuk Wilayah Jawa dan Bali?

\section{Kegunaan}

Dengan diketahuinya kinerja atau produktivitas kerja perekonomin Wilayah Jawa dan Bali terkait kemampuan daya saing dan progresifitas pertumbuhan di berbagai sektor ekonomi, maka dapat diketahui sejauhmana kesiapan Jawa dan Bali dalam melaksanakan kebijakan transformasi ekonomi nya. Dengan demikian, dapat dirumuskan usulan berbagai 
alternatif kebijakan untuk mengantisipasi berbagai hambatan yang dapat mnganggu kelamcaran proses transformasi ekonomi Jawa- Bali dan ekonomi nasional secara umum.

\section{Metodologi Kajian}

Untuk menganalisis permasalahan dalam nasakah kebijakan ini akan digunakan pendekatan kuantitatif dan menggunakan data sekunder. Penelitian ini menggunakan data: PDRB (PDRB ADHK 2010) dari 7 Provinsi di Wilayah Jawa dan Bali pada tahun 2010 dan 2019. Untuk mengetahui sejauh mana tingkat spesialisasi sektor-sektor ekonomi di Wilayah Jawa dan Bali yang memanfaatkan sektor basis atau leading sector selama periode pengamatan akan digunakan metode Location Quotient (LQ); sedangkan, untuk melihat sektor-sektor ekonomi yang tumbuh secara progresif dan mempunyai daya saing yang tinggi di Wilayah Jawa dan Bali akan digunakan analisis shift share. Dengan diketahuinya kinerja sektoral dalam kurun waktu 2010 -2019 maka diharapkan akan dapat dirumuskan alterantif kebijakan yang relevan untuk mendukung kebijakan tranfromasi ekononomi di Wilayah Jawa-Bali.

\section{Studi Literatur}

Economic base theory menyatakan bahwa faktor penentu utama dalam pertumbuhan ekonomi pada suatu daerah berhubungan langsung dengan permintaan akan barang dan jasa dari luar daerah atau besarnya peningkatan ekspor dari wilayah tersebut (Asyard, 1999). Kegiatan ekonomi dikelompokkan menjadi dua yakni kegiatan basis dan kegiatan non-basis, namun hanya kegiatan basis saja yang dapat mendorong pertumbuhan ekonomi. Glasson (1977) menyatakan bahwa semakin banyaknya sektor basis dalam suatu wilayah maka akan menambah pendapatan ke wilayah tersebut, menambah permintaan terhadap darang dan jasa yang ada di dalam wilayah tersebut dan juga akan menimbulkan kenaikan volume sektor non basis. Sektor basis merupakan penggerak utama dalam perekonomian suatu wilayah karena sektor basis berhubungan langsung dengan permintaan dari luar dan sektor non-basis berhubungan secara tidak langsung dan melalui sektor basis terlebih dahulu. Analisis Location Quotient (LQ) dapat digunakan untuk mengetahui mana sektro basis dan non basisi dari speroekonomian suatau wilayah. Sementara itu, untuk mengetahui bagaimana perkembangan suatu sektor di suatu wilayah dengan membandingkan secara relatif dengan sektor lainnya dapat digunakan analisis shift share (Soepono, 1993).

\section{Analisis Location Quotient (LQ)}

Analisis location quotient (LQ) merupakan suatu analisis yang digunakan untuk mengetahui sejauh mana tingkat spesialisasi sektor-sektor ekonomi di suatu wilayah yang memanfaatkan sektor basis atau leading sektor. Location quotient menghitung perbandingan share output sektor i di kota atau kabupaten dan share out sektor i di provinsi. Sektor unggulan disini berarti sektor bisnis yang tidak akan habis apabila dieksploitasi oleh pemerintah wilayah. Menurut Hood (1998), menyatakan bahwa location quotient adalah suatu alat pengembangan ekonomi yang lebih sederhana dengan segala kelebihan dan keterbatasannya. Teknik LQ merupakan salah satu pendekatan yang umum digunakan dalam model ekonomi basis sebagai langkah awal untuk memahami sektor kegiatan yang menjadi pemicu pertumbuhan. LQ mengukur konsentrasi relatif atau derajat spesialisasi kegiatan ekonomi melalui pendekatan perbandingan. Teknik LQ banyak digunakan untuk 
membahas kondisi perekonomian, mengarah pada identifikasi spesialisasi kegiatan perekonomian atau mengukur konsentrasi relative kegiatan ekonomi untuk mendapatkan gambaran dalam penetapan sector unggulan sebagai leading sektor suatu kegiatan ekonomi industri. Dasar pembahasannya sering difokuskan pada aspek tenaga kerja dan pendapatan. Teknik LQ belum bisa memberikan kesimpulan akhir dari sektor-sektor yang teridentifikasi sebagai sektor strategis. Namun untuk tahap pertama sudah cukup memberi gambaran akan kemampuan suatu wilayah dalam sektor yang teridentifikasi. Rumus matematika yang digunakan untuk membandingkan kemampuan sektor-sektor dari wilayah tersebut dapat dilakukan dengan pendekatan Pendekatan Nilai Tambah/ Pendapatan (PDRB), sebagai berikut:

$$
\mathrm{LQ}=\left\lceil\frac{X_{i r} / X_{r}}{X_{i n} / X_{n}}\right\rceil
$$

Dimana :

$$
\begin{array}{ll}
X_{i r} & =\text { sektor } i \text { di daerah (Provinsi) } \\
X_{r} & =\text { jumlah seluruh sektor di daerah (Provinsi) } \\
X_{i n} & =\text { sektor } i \text { di wilayah yang lebih luas (misal se Jawa-Bali) } \\
X_{n} & =\text { jumlah seluruh sektor di wilayah yang lebih luas (misal se Jawa-Bali) }
\end{array}
$$

Jika hasil perhitungan dari formulasi di atas menghasilkan:

a. LQ $>1$ artinya, komoditas itu menjadi basis atau menjadi sumber pertumbuhan. Komoditas memiliki keunggulan komparatif, hasilnya tidak saja dapat memenuhi kebutuhan di wialyah bersangkutan akan tetapi juga dapat diekspor ke luar wilayah.

b. $\quad \mathrm{LQ}=1$ komoditas itu tergolong non-basis, tidak memiliki keunggulan komparatif. Produksinya hanya cukup untuk memenuhi kebutuhan wilayah sendiri dan tidak mampu untuk diekspor.

c. LQ $<1$ komoditas ini juga termasuk non-basis. Produksi komoditas di suatu wilayah tidak dapat memenuhi kebutuhan sendiri sehingga perlu pasokan atau impor dari luar.

Kelebihan metode LQ dalam mengidentifikasi komoditas unggulan antara lain:

a. LQ merupakan suatu alat analisis yang digunakan dengan mudah dan sederhana, serta cepat penggunaannya.

b. LQ dapat digunakan sebagai analisis awal untuk suatu wilayah, kemudian dapat dilanjutkan dengan alat analisis lainnya.

c. Perubahan tingkat spesialisasi dari setiap sektor dapat pula diketahui dengan membandingkan LQ dari tahun ke tahun.

d. Penerapannya tidak memerlukan program pengolahan data yang rumit.

Dari segi keterbatasannya, metode LQ terbatas dalam:

a. Karena kesederhanaan pendekatan LQ ini, maka yang dituntut adalah akurasi data. Sebaik apapun hasil olahan LQ tidak akan banyak manfaatnya jika data yang digunakan tidak valid. 
b. Pengumpulan data yang sangat valid sangat sulit dilakukan di lapangan sehingga mempersulit pengumpulan data.

c. Deliniasi wilayah kajian. Untuk menetapkan batasan wilayah yang dikaji dan ruang lingkup aktivitas, acuannya sering tidak jelas. Akibatnya hasil hitungan LQ terkadang aneh, tidak sama dengan apa yang kita duga.

d. Perlu diketahui bahwa nilai LQ dipengaruhi oleh berbagai faktor. Nilai hasil perhitungannya bias, karena tingkat disagregasi peubah spesialisasi, pemilihan peubah acuan, pemilihan entity yang diperbandingkan, pemilihan tahun dan kualitas data.

\section{Analisis Shift Share}

Perubahan struktur perekonomian dapat terjadi sebagai akibat dari pelaksanaan pembangunan ekonomi. Sebuah sektor ekonomi bisa menjadi kurang penting peranannya dalam pembentukan PDB/ PDRB digeser oleh sektor lainnya sesuai dengan kondisi ekonomi yang sedang terjadi saat itu. Fenomena transformasi ekonomi ini bisa berbeda antar Provinsi yang selanjutnya bisa mengubah posisi suatu Provinsi di dalam perekonomian nasional. Perbedaan tersebut disebabkan adanya perbedaan seperti penyediaan bahan baku, teknologi, investasi, dan sumber daya manusia. Dengan adanya perbedaan tersebut maka diketahui transformasi ekonomi di suatu wilayah adalah penting terutama untuk pedoman dalam mengalokasikan dana pembangunan yang terbatas, sumberdaya manusia, teknologi dan input-input penting untuk produksi antar Provinsi. Dalam hal ini analisis yang umumnya digunakan untuk mengevaluasi perubahan struktur ekonomi adalah analisis shiftshare. Analisis shift share membandingkan perbedaan laju pertumbuhan berbagai sektor industri di daerah dengan wilayah nasional (Tarigan, 2005). Analisis shift-share mempunyai beberapa kegunaan yaitu: (1) mengetahui sejauh mana peranan petumbuhan ekonomi secara keseluruhan. (2). mengetahui sejauh mana pengaruh pertumbuhan ekonomi terhadap pertumbuhan suatu sektor. (4). mengetahui komponen yang mempengaruhi kesempatan kerja nyata. (5). mengetahui pergeseran ekonomi regional sebagai akibat perubahan ekonomi nasional maupun ekonomi regional itu sendiri.

Pendekatan shift share ini pertama kali diperkenalkan oleh Dunn tahun 1960 untuk menjelaskan perubahan ekonomi yang dipengaruhi oleh sektor secara nasional, regional dan lokal (Goschim, 2014). Pendekatan ini juga digunakan oleh Perloff et al. (1960) untuk studi yang berkaitan dengan data ketenaga-kerjaan. Teknik ini banyak digunakan dalam menganalisis dampak pertumbuhan regional, khususnya pertumbuhan lapangan kerja, diterapkan untuk menggambarkan tren pertumbuhan historis, memperkirakan pertumbuhan regional dan menganalisis efek dari inisiatif kebijakan serta mengembangkan perencanaan strategis untuk komunitas (Rice dan Horton, 2010).

Menurut metode ini, pertumbuhan ekonomi suatu wilayah dipengaruhi oleh tiga komponen utama, yakni pertumbuhan nasional (Komponen Pertumbuhan Nasional/KPN), pertumbuhan sektoral atau bauran industri (Komponen Pertumbuhan Proporsional/KPP), dan pertumbuhan daya saing (Komponen Pertumbuhan Pangsa Wilayah/KPPW). Sementara itu, Shift Share (SSA) merupakan penjumlahan dari Komponen Pertumbuhan Nasional, Komponen Pertumbuhan Proporsional dan Komponen Pertumbuhan Pangsa Wilayah. Metode penghitungan dari masing-masing komponen adalah sebagai berikut:

\section{a. Komponen Pertumbuhan Jawa-Bali (KPJB).}


Komponen pertumbuhan Jawa-Bali merupakan pertambahan pendapatan atau tingkat produksi suatu daerah (Provinsi) agar bisa tumbuh paling tidak sama dengan laju pertumbuhan daerah acuan (Jawa-Bali) dalam suatu periode tertentu. KPJB berfungsi untuk melihat struktur atau posisi relatif suatu daerah dalam kaitannya dengan pertumbuhan ekonomi secara menyeluruh di wilayah yang menaunginya. Dalam Kajian ini nilai KPJB menggunakan total nilai PDRB dari 7 provinsi di Jawa dan Bali (sesuai cakupan penelitian). Penghitungan KPJB menggunakan formula sebagai berikut:

$$
\mathrm{KPJB}=\left\lceil\frac{X_{t 1}}{X_{t 0}}-1\right\rceil
$$

Dimana:

KPJB = Komponen Pertumbuhan 7 Provinsi di Jawa dan Bali

$X_{t}=$ Total PDRB 7 Provinsi di Jawa dan Bali pada periode akhir (2019)

$X_{t o}=$ Total PDRB 7 Provinsi di Jawa dan Bali pada periode awal (2010)

\section{b. Komponen Pertumbuhan Proporsional/KPP}

KPP merupakan alat untuk mengukur tingkat pertumbuhan produksi suatu wilayah lebih cepat atau lebih lambat dari pertumbuhan produksi nasional (dalam hal ini JawaBali) karena tingginya konsentrasi industri (sektor) regional. KPP atau bisa disebut sebagai proportionaly shift ini biasanya dipengaruhi oleh perubahan permintaan akhir, ketersediaan bahan baku, dan kebijakan sektoral. Selain itu komponen pertumbuhan proporsional tumbuh karena perbedaan sektor dalam permintaan produk akhir, perbedaan ketersediaan bahan mentah, perbedaan kebijakan industri dan perbedaan struktur, dan keragaman pasar. Penghitungan KPP menggunakan formula sebagai berikut:

$$
\mathrm{KPP}=\left\lceil\frac{X_{j(t 1)}}{X_{j(t 0)}}-\frac{X_{t 1}}{X_{t 0}}\right\rceil
$$

Dimana:

KPP = Komponen Pertumbuhan Proporsional

$X_{(t)} \quad=$ Total PDRB 7 Provinsi di Jawa-Bali sektor i pada periode akhir (2019)

$X j_{(t)}=$ Total PDRB 7 Provinsi di Jawa-Bali sektor i pada periode awal (2010)

$X_{t t}=$ Total PDRB 7 Provinsi di Jawa dan Bali pada periode akhir (2019)

$X_{t o}=$ Total PDRB 7 Provinsi di Jawa dan Bali pada periode awal (2010)

$\mathrm{KPP}<\mathrm{O}=$ Menunjukkan bahwa sector i pada provinsi $\mathrm{j}$ pertumbuhannya lebih lambat dibanding dengan pertumbuhan sektor yang sama se Jawa-Bali

$\mathrm{KPP}>\mathrm{O}=$ Menunjukkan bahwa sector i pada provinsi $\mathrm{j}$ pertumbuhannya lebih cepat dibanding dengan pertumbuhan sektor yang sama se Jawa-Bali

\section{c. Komponen Pertumbuhan Pangsa Wilayah/KPPW}

KPPW (biasa disebut dengan different shift) mengukur daya saing suatu sektor di suatu provinsi dibandingkan dengan pertumbuhan sektor yang sama di provinsi lain. KPPW 
terjadi karena peningkatan atau penurunan output di suatu wilayah yang disebabkan oleh keunggulan komparatif, akses ke pasar input dan output, maupun infrastruktur ekonomi. Penghitungan KPPW menggunakan formula sebagai berikut:

$$
\mathrm{KPPW}=\left\lceil\frac{X_{i j(t 1)}}{X_{i j(t 0)}}-\frac{X_{j(t 1)}}{X_{j(t 0)}}\right\rceil
$$

Dimana:

KPPW = Komponen Pertumbuhan Pangsa Wilayah

$X i i_{(t)} \quad=P D R B$ sektor i di provinsi j pada periode akhir (2019)

$X i j_{(t)} \quad=P D R B$ sektor i di provinsi j pada periode awal (2010)

$X j_{(t)} \quad=$ Total PDRB 7 Provinsi di Jawa-Bali sektor i pada periode akhir (2019)

$X_{(t)}=$ Total PDRB 7 Provinsi di Jawa-Bali sektor i pada periode awal (2010)

KPPW $<0$ berarti sector $\mathrm{i}$ di provinsi $\mathrm{j}$ relatif tidak mempunyai daya saing dibandingkan dengan sektor yang sama se Jawa-Bali

KPPW $>0$ berarti sector i di provinsi j mempunyai daya saing yang baik dibandingkan dengan sektor yang sama se Jawa-Bali

\section{d. Menghitung Pergeseran Bersih (PB)}

Apabila komponen pertumbuhan proporsional dan komponen pertumbuhan pangsa wilayah dijumlahkan maka akan diperoleh pergeseran bersih (PB) yang dapat digunakan untuk mengidentifikasikan pertumbuhan suatu sektor perekonomian. Perumbuhan bersih pada sektor i pada provinsi j dapat difromulasikan sebagai berikut:

$\mathbf{P B}_{\mathrm{ij}}=\mathbf{K P} \mathbf{P}_{\mathrm{ij}}+\mathrm{KPW}_{\mathrm{ij}}$

Dimana:

$P B_{i j}=$ Pergeseran bersih sektor i di provinsi j

$K P P_{i j} \quad=$ Komponen Pertumbuhan Proporsional sektor i di provinsi j

$K P W_{i j} \quad=$ Komponen Pertumbuhan Pangsa Wilayah sektor i pada provinsi j

$P B_{i j}<0 \quad$ berarti pertumbuhan sector i di provinsi j mundur (tumbuh negatif)

- $\quad P B_{i j}>0$ berarti pertumbuhan sector i di provinsi j tumbuh yang progresif (maju)

\section{Analisis dan Temuan}

\section{Perekonomian Jawa dan Bali}

Perekonomian Jawa-Bali dalam kurun waktu 2011-2019 tumbuh rata-rata sebesar $5,81 \%$, lebih besar dibanding rata-rata pertumbuhan ekonomi nasional yang sebesar $5,37 \%$ untuk kurun waktu yang sama. Namun, pada tahun 2020 akibat pandemic covid 19, pertumbuhan ekonomi Jawa Bali terkontraksi sebesar 3,60\% terkontraksi lebih besar dibanding perekonomian nasional yang terkonstraksi sebesar 2,07\%. Gambar 2 berikut memperlihatkan tren pertumbuhan ekonomi Jawa Bali dalam kurun waktu 2011-2020. 
Tahun 2020, diantara 7 Provinsi di Jawa dan Bali, pertumbuhan ekonomi Provinsi Bali terkontraksi paling dalam sebesar 9,31\%, disusul Provinsi Banten yang terkontraksi sebesar $3,38 \%$. Sementara itu, 5 provinsi lain di Jawa dan Bali terkontraksi pada kisaran 2,4-2,7\%. Penurunan perekonomian Bali disebabkan oleh ketergantuang yang cukup tinggi pada sektor Pariwisata, sehingga ketika sektor ini terkena imbas akibat pademik Covid-19, maka perekonomian terkontraksi cukup dalam. Data memperlihatkan bahwa devisa pariwisata di Provinsi Bali tahun 2020 menurun cukup tajam, dari 7.192 Milyar USD tahun 2019 turun menjadi hanya 1.226 Milyar USD tahun 2020. Sementara, kalau dilihat dari jumlah kunjungan wisman, tahun 2019 sebanyak 6.272 orang turun menjadi 1.069 orang pada tahun 2020. Fenomena ini cukup menarik untuk dianalisis khusunya dari segi struktur perekonomian di wilayah Jawa-Bali.

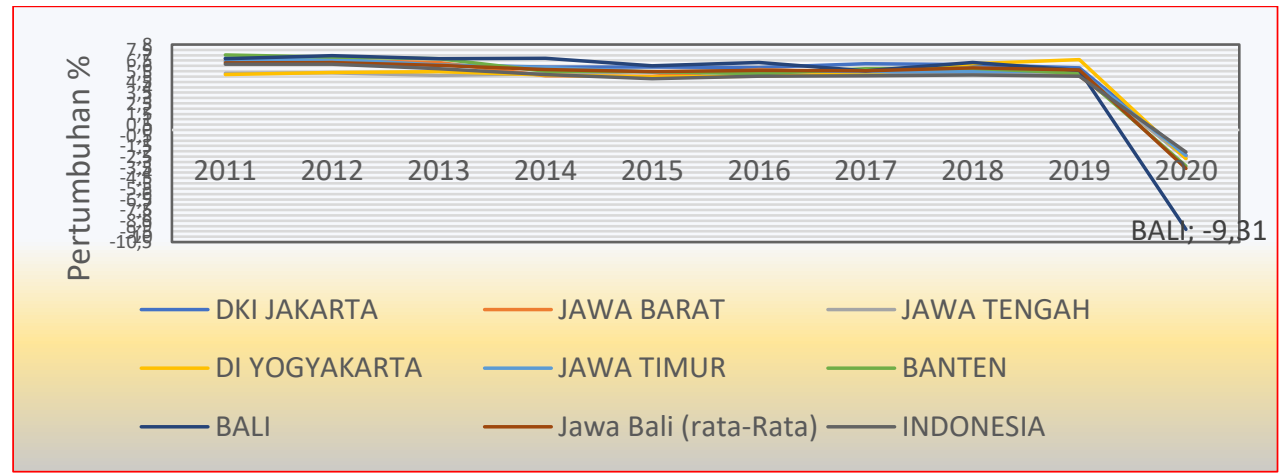

Gambar 2. Tren Pertumbuhan Ekonomi 7 Provinsi di Jawa dan Bali 2011-2020

Sumber: Diolah dari BPS

\section{Hasil Analisis LQ dan Pembahasan}

Hasil analisis LQ perekonomian Jawa Bali tahun 2010 dan 2019 terlihat dalam Tabel 1 dan Table 2 berikut:

\begin{tabular}{|c|c|c|c|c|c|c|c|c|c|c|c|c|c|c|c|c|c|}
\hline \multicolumn{18}{|c|}{ Tabel 1: Hasil Perhitungan Analisis LQ 7 Provinsi di Jawa dan Bali Tahun 2010} \\
\hline $\begin{array}{l}\text { PROVI } \\
\text { NSI }\end{array}$ & \multicolumn{17}{|c|}{ Sektor } \\
\hline & 1 & 2 & 3 & 4 & 5 & 6 & 7 & 8 & 9 & $\begin{array}{l}1 \\
0\end{array}$ & $\begin{array}{l}1 \\
1\end{array}$ & $\begin{array}{l}1 \\
2\end{array}$ & $\begin{array}{l}1 \\
3\end{array}$ & $\begin{array}{l}1 \\
4\end{array}$ & $\begin{array}{l}1 \\
5\end{array}$ & $\begin{array}{l}1 \\
6\end{array}$ & $\begin{array}{l}1 \\
7\end{array}$ \\
\hline $\begin{array}{l}\text { DKI } \\
\text { JAKAR } \\
\text { TA }\end{array}$ & 0.01 & $\begin{array}{c}0 . \\
10\end{array}$ & $\begin{array}{c}0 . \\
48\end{array}$ & $\begin{array}{r}0 . \\
68\end{array}$ & $\begin{array}{c}0 . \\
59\end{array}$ & $\begin{array}{r}1 . \\
40\end{array}$ & $\begin{array}{r}1 . \\
07\end{array}$ & $\begin{array}{r}0 . \\
80\end{array}$ & $\begin{array}{r}1 . \\
18\end{array}$ & $\begin{array}{r}1 . \\
57\end{array}$ & $\begin{array}{r}2 . \\
27\end{array}$ & $\begin{array}{r}1 . \\
98\end{array}$ & $\begin{array}{r}3 . \\
04\end{array}$ & $\begin{array}{r}1 . \\
48\end{array}$ & $\begin{array}{r}1 . \\
56\end{array}$ & $\begin{array}{r}1 . \\
62\end{array}$ & $\begin{array}{r}1 . \\
54\end{array}$ \\
\hline $\begin{array}{l}\text { JAWA } \\
\text { BARAT }\end{array}$ & 1.09 & $\begin{array}{r}1 . \\
28\end{array}$ & $\begin{array}{r}1 . \\
51\end{array}$ & $\begin{array}{r}1 . \\
31\end{array}$ & $\begin{array}{r}0 . \\
90\end{array}$ & $\begin{array}{r}0 . \\
69\end{array}$ & $\begin{array}{r}0 . \\
98\end{array}$ & $\begin{array}{r}1 . \\
19\end{array}$ & $\begin{array}{c}0 . \\
56\end{array}$ & $\begin{array}{r}0 . \\
48\end{array}$ & $\begin{array}{r}0 . \\
49\end{array}$ & $\begin{array}{r}0 . \\
31\end{array}$ & $\begin{array}{c}0 . \\
16\end{array}$ & $\begin{array}{r}0 . \\
75\end{array}$ & $\begin{array}{r}0 . \\
60\end{array}$ & $\begin{array}{r}0 . \\
62\end{array}$ & $\begin{array}{r}0 . \\
83\end{array}$ \\
\hline $\begin{array}{l}\text { JAWA } \\
\text { TENGA } \\
\text { H }\end{array}$ & 1.77 & $\begin{array}{r}0 . \\
82\end{array}$ & $\begin{array}{r}1 . \\
17\end{array}$ & $\begin{array}{r}0 . \\
23\end{array}$ & $\begin{array}{r}1 . \\
01\end{array}$ & $\begin{array}{r}1 . \\
03\end{array}$ & $\begin{array}{r}0 . \\
93\end{array}$ & $\begin{array}{r}0 . \\
86\end{array}$ & $\begin{array}{r}0 . \\
71\end{array}$ & $\begin{array}{c}0 . \\
70\end{array}$ & $\begin{array}{r}0 . \\
61\end{array}$ & $\begin{array}{r}0 . \\
49\end{array}$ & $\begin{array}{r}0 . \\
13\end{array}$ & $\begin{array}{r}0 . \\
91\end{array}$ & $\begin{array}{r}0 . \\
80\end{array}$ & $\begin{array}{r}0 . \\
70\end{array}$ & $\begin{array}{r}0 . \\
78\end{array}$ \\
\hline
\end{tabular}




\begin{tabular}{|c|c|c|c|c|c|c|c|c|c|c|c|c|c|c|c|c|c|}
\hline $\begin{array}{l}\text { DI } \\
\text { YOGYA } \\
\text { KARTA }\end{array}$ & 1.24 & $\begin{array}{r}0 . \\
24\end{array}$ & $\begin{array}{r}0 . \\
48\end{array}$ & $\begin{array}{l}0 . \\
33\end{array}$ & $\begin{array}{r}1 . \\
36\end{array}$ & $\begin{array}{r}0 . \\
95\end{array}$ & $\begin{array}{l}0 . \\
50\end{array}$ & $\begin{array}{r}1 . \\
63\end{array}$ & $\begin{array}{r}2 . \\
09\end{array}$ & $\begin{array}{r}1 . \\
99\end{array}$ & $\begin{array}{r}0 . \\
69\end{array}$ & $\begin{array}{r}1 . \\
99\end{array}$ & $\begin{array}{r}0 . \\
50\end{array}$ & $\begin{array}{r}2 . \\
12\end{array}$ & $\begin{array}{r}2 . \\
55\end{array}$ & $\begin{array}{r}2 . \\
52\end{array}$ & $\begin{array}{r}1 . \\
33\end{array}$ \\
\hline $\begin{array}{l}\text { JAWA } \\
\text { TIMUR }\end{array}$ & 1.49 & $\begin{array}{r}2 . \\
10\end{array}$ & $\begin{array}{r}1 . \\
\mathrm{OO}\end{array}$ & $\begin{array}{r}1 . \\
01\end{array}$ & $\begin{array}{r}1 . \\
26\end{array}$ & $\begin{array}{r}0 . \\
90\end{array}$ & $\begin{array}{c}1 . \\
12\end{array}$ & $\begin{array}{r}0 . \\
79\end{array}$ & $\begin{array}{r}1 . \\
12\end{array}$ & $\begin{array}{r}1 . \\
0 O\end{array}$ & $\begin{array}{r}0 . \\
49\end{array}$ & $\begin{array}{r}0 . \\
47\end{array}$ & $\begin{array}{r}0 . \\
35\end{array}$ & $\begin{array}{r}0 . \\
77\end{array}$ & $\begin{array}{r}0 . \\
76\end{array}$ & $\begin{array}{r}0 . \\
58\end{array}$ & $\begin{array}{r}0 . \\
78\end{array}$ \\
\hline $\begin{array}{l}\text { BANTE } \\
\mathbf{N}\end{array}$ & 0.68 & $\begin{array}{r}0 . \\
37\end{array}$ & $\begin{array}{r}1 . \\
35\end{array}$ & $\begin{array}{r}3 . \\
32\end{array}$ & $\begin{array}{r}1 . \\
22\end{array}$ & $\begin{array}{l}0 . \\
80\end{array}$ & $\begin{array}{l}0 . \\
80\end{array}$ & $\begin{array}{r}1 . \\
72\end{array}$ & $\begin{array}{l}0 . \\
54\end{array}$ & $\begin{array}{l}0 . \\
86\end{array}$ & $\begin{array}{l}0 . \\
54\end{array}$ & $\begin{array}{r}2 . \\
16\end{array}$ & $\begin{array}{r}0 . \\
41\end{array}$ & $\begin{array}{r}0 . \\
53\end{array}$ & $\begin{array}{r}0 . \\
92\end{array}$ & $\begin{array}{r}1 . \\
32\end{array}$ & $\begin{array}{l}0 . \\
72\end{array}$ \\
\hline BALI & 1.90 & $\begin{array}{r}0 . \\
47\end{array}$ & $\begin{array}{r}0 . \\
24\end{array}$ & $\begin{array}{r}0 . \\
46\end{array}$ & $\begin{array}{r}2 . \\
96\end{array}$ & $\begin{array}{l}0 . \\
88\end{array}$ & $\begin{array}{r}0 . \\
55\end{array}$ & $\begin{array}{r}2 . \\
13\end{array}$ & $\begin{array}{r}4 . \\
49\end{array}$ & $\begin{array}{r}1 . \\
31\end{array}$ & $\begin{array}{r}0 . \\
87\end{array}$ & $\begin{array}{r}1 . \\
39\end{array}$ & $\begin{array}{r}0 . \\
51\end{array}$ & $\begin{array}{r}1 . \\
60\end{array}$ & $\begin{array}{r}1 . \\
45\end{array}$ & 10 & $\begin{array}{l}0 . \\
78\end{array}$ \\
\hline
\end{tabular}

\section{Keterangan:}

1. Pertanian, Kehutanan, dan Perikanan

10. Informasi dan Komunikasi

2. Pertambangan dan Penggalian

3. Industri Pengolahan

4. Pengadaan Listrik dan Gas

11. Jasa Keuangan dan Asuransi

12. Real Estat

5. Pengadaan Air, Pengelolaan Sampah, Limbah

13. Jasa Perusahaan

dan Daur Ulang

6. KontruksiPerdagangan Besar dan Eceran,

14. Administrasi Pemerintahan, Pertahanan \& Jaminan Sosial Wajib

7. Reparasi Mobil dan Sepeda Motor

15. Jasa Pendidikan

16. Jasa Kesehatan dan Kegiatan Sosial

8. Transportasi dan Pergudangan

17. Jasa Lainnya

9. Penyedia Akomodasi \& Makan Minum

Tabel 2. Hasil Perhitungan Analisis LQ 7 Provinis di Jawa-Bali Tahun 2019

\begin{tabular}{|c|c|c|c|c|c|c|c|c|c|c|c|c|c|c|c|c|c|}
\hline PROVINSI & \multicolumn{17}{|c|}{ Sektor } \\
\hline & 1 & 2 & 3 & 4 & 5 & 6 & 7 & 8 & 9 & 10 & 11 & 12 & 13 & 14 & 15 & 16 & 17 \\
\hline $\begin{array}{l}\text { DKI } \\
\text { JAKARTA }\end{array}$ & $\begin{array}{c}0 . \\
01\end{array}$ & $\begin{array}{l}0 . \\
07\end{array}$ & $\begin{array}{r}0 . \\
42\end{array}$ & $\begin{array}{r}0 . \\
98\end{array}$ & $\begin{array}{l}0 . \\
55\end{array}$ & $\begin{array}{c}1 \\
18\end{array}$ & $\frac{1 .}{00}$ & $\begin{array}{c}0 . \\
91\end{array}$ & $\begin{array}{r}1 . \\
07\end{array}$ & $\begin{array}{c}1 . \\
63\end{array}$ & $\begin{array}{r}2 \\
22\end{array}$ & $\begin{array}{r}1 . \\
78\end{array}$ & $\begin{array}{l}3 . \\
02\end{array}$ & $\begin{array}{r}1 . \\
40\end{array}$ & $\begin{array}{r}1 . \\
28\end{array}$ & $\begin{array}{c}1 . \\
48\end{array}$ & $\begin{array}{r}1 . \\
65\end{array}$ \\
\hline $\begin{array}{l}\text { JAWA } \\
\text { BARAT }\end{array}$ & $\begin{array}{c}1 . \\
05\end{array}$ & 81 & $\begin{array}{r}1 . \\
54\end{array}$ & $\begin{array}{r}1 . \\
11\end{array}$ & 1. & $\begin{array}{l}0 . \\
84\end{array}$ & 0. & 1. & $\begin{array}{c}0 . \\
59\end{array}$ & $\begin{array}{r}0 . \\
61\end{array}$ & $\begin{array}{l}0 \\
50\end{array}$ & $\begin{array}{c}0 . \\
36\end{array}$ & $\begin{array}{l}0 . \\
16\end{array}$ & $\begin{array}{c}0 . \\
70\end{array}$ & $\begin{array}{c}0 . \\
78\end{array}$ & $\begin{array}{c}0 . \\
74\end{array}$ & $\begin{array}{c}0 . \\
93\end{array}$ \\
\hline $\begin{array}{l}\text { JAWA } \\
\text { TENGAH }\end{array}$ & $\begin{array}{r}1 . \\
85\end{array}$ & $\frac{1 .}{06}$ & 22 & $\begin{array}{c}0 . \\
34\end{array}$ & 0. & 03 & 92 & 88 & $\begin{array}{c}0 . \\
72\end{array}$ & $\begin{array}{l}0 . \\
72\end{array}$ & $\begin{array}{l}0 \\
55\end{array}$ & $\begin{array}{c}0 . \\
53\end{array}$ & $\begin{array}{l}0 . \\
14\end{array}$ & $\begin{array}{c}0 . \\
92\end{array}$ & $\frac{1 .}{09}$ & $\begin{array}{c}0 . \\
78\end{array}$ & $\begin{array}{c}0 . \\
74\end{array}$ \\
\hline $\begin{array}{l}\text { DI } \\
\text { YOGYAK } \\
\text { ARTA }\end{array}$ & $\begin{array}{r}1 . \\
17\end{array}$ & $\begin{array}{c}0 . \\
26\end{array}$ & $\begin{array}{l}0 . \\
45\end{array}$ & $\begin{array}{r}0 . \\
49\end{array}$ & 30 & $\frac{1 .}{08}$ & $\begin{array}{r}0 . \\
52\end{array}$ & 32 & $\begin{array}{r}2 . \\
10\end{array}$ & $\begin{array}{r}1 . \\
58\end{array}$ & $\begin{array}{l}0 \\
75\end{array}$ & $\begin{array}{r}2 . \\
01\end{array}$ & $\begin{array}{r}0 . \\
42\end{array}$ & $\begin{array}{r}2 . \\
61\end{array}$ & $\begin{array}{r}2 . \\
42\end{array}$ & $\begin{array}{l}2 . \\
35\end{array}$ & $\begin{array}{r}1 . \\
17\end{array}$ \\
\hline $\begin{array}{l}\text { JAWA } \\
\text { TIMUR }\end{array}$ & $\begin{array}{r}1 . \\
50\end{array}$ & $\begin{array}{r}2 . \\
47\end{array}$ & $\begin{array}{c}1 . \\
08\end{array}$ & $\frac{0 .}{85}$ & 27 & 92 & 17 & $\begin{array}{c}0 . \\
74\end{array}$ & $\begin{array}{r}1 . \\
19\end{array}$ & 83 & $\begin{array}{l}0 \\
51\end{array}$ & $\begin{array}{l}0 . \\
48\end{array}$ & $\begin{array}{l}0 . \\
28\end{array}$ & $\begin{array}{r}0 . \\
77\end{array}$ & $\begin{array}{r}0 . \\
74\end{array}$ & $\begin{array}{l}0 . \\
61\end{array}$ & $\begin{array}{r}0 . \\
60\end{array}$ \\
\hline BANTEN & $\begin{array}{r}0 . \\
80\end{array}$ & $\begin{array}{r}0 . \\
31\end{array}$ & 21 & $\begin{array}{r}2 . \\
92\end{array}$ & 26 & 00 & 86 & 60 & $\begin{array}{r}0 . \\
54\end{array}$ & 84 & $\begin{array}{l}0 \\
59\end{array}$ & $\begin{array}{r}2 . \\
49\end{array}$ & $\begin{array}{l}0 . \\
38\end{array}$ & $\begin{array}{l}0 . \\
65\end{array}$ & $\begin{array}{l}0 . \\
85\end{array}$ & $\begin{array}{c}1 . \\
11\end{array}$ & $\begin{array}{r}0 . \\
66\end{array}$ \\
\hline BALI & $\begin{array}{r}1 . \\
97\end{array}$ & $\begin{array}{r}0 . \\
43\end{array}$ & 23 & $\begin{array}{c}0 . \\
64\end{array}$ & 73 & 99 & 59 & 83 & $\begin{array}{r}4 . \\
34\end{array}$ & 01 & $\begin{array}{l}0 \\
85\end{array}$ & $\begin{array}{r}1 . \\
29\end{array}$ & $\begin{array}{r}0 . \\
40\end{array}$ & $\begin{array}{r}2 . \\
01\end{array}$ & $\begin{array}{r}1 . \\
53\end{array}$ & $\begin{array}{c}2 . \\
14\end{array}$ & $\begin{array}{r}0 . \\
71\end{array}$ \\
\hline
\end{tabular}

Keterangan: 
1. Pertanian, Kehutanan, dan Perikanan

2. Pertambangan dan Penggalian

3. Industri Pengolahan

4. Pengadaan Listrik dan Gas

5. Pengadaan Air, Pengelolaan Sampah, Limbah dan Daur Ulang

6. Kontruksi Perdagangan Besar dan Eceran,

7. Reparasi Mobil dan Sepeda Motor

8. Transportasi dan Pergudangan

9. Penyedia Akomodasi \& Makan Minum
10. Informasi dan Komunikasi

11. Jasa Keuangan dan Asuransi

12. Real Estat

13. Jasa Perusahaan

14. Administrasi Pemerintahan, Pertahanan \& Jaminan Sosial Wajib

15. Jasa Pendidikan

16. Jasa Kesehatan dan Kegiatan Sosial

17. Jasa Lainnya

Hasil perhitungan LQ terhadap perekonoman Jawa-Bali pada tahun 2010 dan 2019 secara umum tidak banyak mengalami perubahan struktur ekonomi. Sektor-sektor yang menjadi basis atau menjadi sumber pertumbuhan pada tahun 2010 di masing-masing provinsi di Jawa-Bali pada umumnya tidak mengalami perubahan. Table 3 berikut memperlihatkan hasil pemetaan perubahan struktur ekonomi di 7 provinsi Jawa-Bali:

Table 3. Hasil Pemetaan Perubahan Struktur Ekonomi di 7 Provinsi Jawa-Bali

\begin{tabular}{|c|c|c|c|}
\hline \multirow[b]{2}{*}{ Provinsi } & \multicolumn{3}{|c|}{ Struktur Ekonomi Berdasarkan LQ Tahun 2019} \\
\hline & $\begin{array}{c}\text { Sektor dengan LQ }>1 \\
\text { (Komoditas menjadi basis atau } \\
\text { sumber pertumbuhan, memiliki } \\
\text { keunggulan komparatif, hasilnya } \\
\text { tidak saja dapat memenuhi } \\
\text { kebutuhan di wialyah } \\
\text { bersangkutan akan tetapi juga } \\
\text { dapat diekspor ke luar wilayah) }\end{array}$ & $\begin{array}{l}\text { Sektor dengan LQ } \\
=1 \\
\text { (Komoditas } \\
\text { tergolong non- } \\
\text { basis, tidak } \\
\text { memiliki } \\
\text { keunggulan } \\
\text { komparatif, } \\
\text { produksinya hanya } \\
\text { cukup untuk } \\
\text { memenuhi } \\
\text { kebutuhan wilayah } \\
\text { sendiri dan tidak } \\
\text { mampu untuk } \\
\text { diekspor) }\end{array}$ & $\begin{array}{c}\text { Sektor dengan LQ < } \\
\text { (Komoditas termasuk non- } \\
\text { basis, produksi komoditas } \\
\text { tidak dapat memenuhi } \\
\text { kebutuhan sendiri sehingga } \\
\text { perlu pasokan atau impor } \\
\text { dari luar) }\end{array}$ \\
\hline DKI JAKARTA & $\begin{array}{l}\text { - KontruksiPerdagangan Besar } \\
\text { dan Eceran Penyedia } \\
\text { Akomodasi \& Makan Minum } \\
\text { - Informasi dan Komunikasi } \\
\text { - Jasa Keuangan dan Asuransi } \\
\text { - Real Estat } \\
\text { - Jasa Perusahaan } \\
\text { - Administrasi Pemerintahan, } \\
\text { Pertahanan \& Jaminan Sosial } \\
\text { - Wajib } \\
\text { - Jasa Pendidikan } \\
\text { - Sasa Kesehatan dan Kegiatan } \\
\text { Jasa Lainnya }\end{array}$ & $\begin{array}{ll}\text { - Reparasi } & \text { Mobil } \\
\text { dan } & \text { Sepeda } \\
\text { Motor } & \end{array}$ & 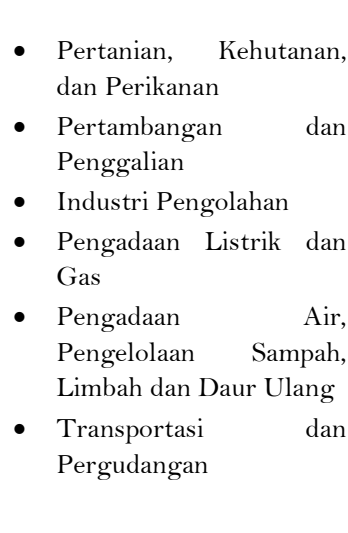 \\
\hline JAWA BARAT & $\begin{array}{l}\text { - Pertanian, Kehutanan, dan } \\
\text { Perikanan } \\
\text { - Industri Pengolahan } \\
\text { - Pengadaan Listrik dan Gas }\end{array}$ & & $\begin{array}{ll}\text { - } & \text { Pertambangan dan } \\
& \text { Penggalian } \\
\text { - } & \text { KontruksiPerdagangan } \\
& \text { Besar dan Eceran } \\
\text { - } & \text { Reparasi Mobil dan Sepeda } \\
& \text { Motor }\end{array}$ \\
\hline
\end{tabular}




\begin{tabular}{|c|c|c|}
\hline & $\begin{array}{l}\text { - Pengadaan Air, Pengelolaan } \\
\text { Sampah, Limbah dan Daur } \\
\text { Ulang } \\
\text { - Transportasi dan Pergudangan }\end{array}$ & $\begin{array}{ll}\text { - } & \text { Penyedia Akomodasi \& } \\
\text { - Makan Minum } \\
\text { - Informasi dan Komunikasi } \\
\text { - Jasa Keuangan dan } \\
\text { Asuransi } \\
\text { - Real Estat } \\
\text { - Jasa Perusahaan } \\
\text { - } \text { Administrasi } \\
\text { Pemerintahan, Pertahanan } \\
\text { \& Jaminan Sosial Wajib } \\
\text { - Jasa Pendidikan } \\
\text { - Jasa Kesehatan dan } \\
\text { Kegiatan Sosial } \\
\text { - Jasa Lainnya }\end{array}$ \\
\hline $\begin{array}{l}\text { JAWA } \\
\text { TENGAH }\end{array}$ & $\begin{array}{l}\text { - Pertanian, Kehutanan, dan } \\
\text { Perikanan } \\
\text { - Pertambangan dan Penggalian } \\
\text { - Industri Pengolahan } \\
\text { - KontruksiPerdagangan Besar } \\
\text { dan Eceran } \\
\text { - Jasa Pendidikan }\end{array}$ & $\begin{array}{l}\text { - } \text { Pengadaan Listrik dan Gas } \\
\text { - Pengadaan Air, } \\
\text { Pengelolaan Sampah, } \\
\text { Limbah dan Daur Ulang } \\
\text { - Reparasi Mobil dan Sepeda } \\
\text { Motor } \\
\text { - Transportasi } \\
\text { Pergudangan } \\
\text { - Penyedia Akomodasi \& } \\
\text { Makan MinumInformasi } \\
\text { dan Komunikasi } \\
\text { - Jasa Keuangan dan } \\
\text { Asuransi } \\
\text { - Real Estat } \\
\text { - Jasa Perusahaan } \\
\text { - Administrasi } \\
\text { Pemerintahan, Pertahanan } \\
\text { \& Jaminan Sosial Wajib } \\
\text { - Jasa Kesehatan dan } \\
\text { Kegiatan Sosial } \\
\text { - Jasa Lainnya }\end{array}$ \\
\hline $\begin{array}{l}\text { DI } \\
\text { YOGYAKARTA }\end{array}$ & $\begin{array}{l}\text { Pertanian, Kehutanan, dan } \\
\text { Perikanan } \\
\text { Pengadaan Air, Pengelolaan } \\
\text { Sampah, Limbah dan Daur } \\
\text { Ulan } \\
\text { - KontruksiPerdagangan Besar } \\
\text { dan Eceran } \\
\text { - Transportasi dan Pergudangan } \\
\text { - Penyedia Akomodasi \& Makan } \\
\text { - Ininum } \\
\text { - Real Estat } \\
\text { Administrasi Pemerintahan, } \\
\text { Pertahanan \& Jaminan Sosial } \\
\text { Wajib } \\
\text { Jasa Pendidikan }\end{array}$ & $\begin{array}{l}\text { - Pertambangan dan } \\
\text { Penggalian } \\
\text { - Industri Pengolahan } \\
\text { - Pengadaan Listrik dan Gas } \\
\text { - Reparasi Mobil dan Sepeda } \\
\text { Motor } \\
\text { - Jasa Keuangan dan } \\
\text { Asuransi } \\
\text { - Jasa Perusahaan }\end{array}$ \\
\hline
\end{tabular}




\begin{tabular}{|c|c|c|c|}
\hline & $\begin{array}{l}\text { - Jasa Kesehatan dan Kegiatan } \\
\text { Sosial } \\
\text { - Jasa Lainnya }\end{array}$ & & \\
\hline JAWA TIMUR & $\begin{array}{l}\text { - Pertanian, Kehutanan, dan } \\
\text { Perikanan } \\
\text { - Pertambangan dan Penggalian } \\
\text { - Industri Pengolahan } \\
\text { - Pengadaan Air, Pengelolaan } \\
\text { Sampah, Limbah dan Daur } \\
\text { Ulan } \\
\text { - Reparasi Mobil dan Sepeda } \\
\text { Motor } \\
\text { - Penyedia Akomodasi \& Makan } \\
\text { Minum }\end{array}$ & & $\begin{array}{l}\text { - } \text { Pengadaan Listrik dan Gas } \\
\text { - KontruksiPerdagangan } \\
\text { Besar dan Eceran } \\
\text { - Transportasi dan } \\
\text { Pergudangan } \\
\text { - Informasi dan Komunikasi } \\
\text { - Jasa Keuangan dan } \\
\text { Asuransi } \\
\text { - Real Estat } \\
\text { - Jasa Perusahaan } \\
\text { - Administrasi } \\
\text { Pemerintahan, Pertahanan } \\
\text { \& Jaminan Sosial Wajib } \\
\text { - Jasa Pendidikan } \\
\text { - Jasa Kesehatan dan } \\
\text { Kegiatan Sosial } \\
\text { - Jasa Lainnya }\end{array}$ \\
\hline BANTEN & $\begin{array}{l}\text { - Industri Pengolahan } \\
\text { - Pengadaan Listrik dan Gas } \\
\text { - Pengadaan Air, Pengelolaan } \\
\text { Sampah, Limbah dan Daur } \\
\text { Ulang } \\
\text { - Transportasi dan Pergudangan } \\
\text { - Real Estat } \\
\text { - Jasa Kesehatan dan Kegiatan } \\
\text { Sosial }\end{array}$ & $\begin{array}{l}\text { Kontruksi } \\
\text { Perdagangan Besar } \\
\text { dan Eceran }\end{array}$ & $\begin{array}{l}\text { - Pertanian, Kehutanan, dan } \\
\text { Perikanan } \\
\text { - Pertambangan } \\
\text { Penggalian } \\
\text { - Reparasi Mobil dan Sepeda } \\
\text { Motor } \\
\text { - Penyedia Akomodasi \& } \\
\text { Makan Minum } \\
\text { - Informasi dan Komunikasi } \\
\text { - Jasa Keuangan dan } \\
\text { Asuransi } \\
\text { - Jasa Perusahaan } \\
\text { - Administrasi } \\
\text { Pemerintahan, Pertahanan } \\
\text { \& Jaminan Sosial Wajib } \\
\text { - Jasa Pendidikan } \\
\text { Jasa Lainnya }\end{array}$ \\
\hline BALI & $\begin{array}{l}\text { - Pertanian, Kehutanan, dan } \\
\text { Perikanan } \\
\text { - Pengadaan Air, Pengelolaan } \\
\text { Sampah, Limbah dan Daur } \\
\text { Ulang } \\
\text { - Transportasi dan Pergudangan } \\
\text { - Penyedia Akomodasi \& Makan } \\
\text { Minum } \\
\text { - Informasi dan Komunikasi } \\
\text { - Real Estat } \\
\text { - Administrasi Pemerintahan, } \\
\text { Pertahanan \& Jaminan Sosial } \\
\text { Wajib } \\
\text { - Jasa Pendidikan }\end{array}$ & & $\begin{array}{l}\text { - Pertambangan dan } \\
\text { Penggalian } \\
\text { - Industri Pengolahan } \\
\text { - Pengadaan Listrik dan Gas } \\
\text { - KontruksiPerdagangan } \\
\text { Besar dan Eceran, } \\
\text { - Reparasi Mobil dan Sepeda } \\
\text { Motor } \\
\text { - Jasa Keuangan dan } \\
\text { Asuransi } \\
\text { - Jasa Perusahaan } \\
\text { - Jasa Lainnya }\end{array}$ \\
\hline
\end{tabular}




\begin{tabular}{|l|l|l|l|}
\hline & $\begin{array}{l}\text { Jasa Kesehatan dan Kegiatan } \\
\text { Sosial }\end{array}$ & & \\
\hline
\end{tabular}

Sementara itu, ada beberapa sektor yang mengalami transformasi dari tahun 2010 ke tahun 2019 baik transformasi dari sektor basis menjadi sektor non-baisi maupuan sebaliknya dari sektor non baiss menjadi sektor basis dan subsistem. Tabel 4 berikut merangkum sektor yang mengalami transformasi.

Table 4. Sektor yang Mengalami Transformasi dari Tahun 2010 ke Tahun 2019

\begin{tabular}{|c|c|c|c|}
\hline & $\begin{array}{c}\text { Sektor yang } \\
\text { mengalamai } \\
\text { Transformasi dari } \\
\text { Non-Basis Menjadi } \\
\text { Basis }\end{array}$ & $\begin{array}{c}\text { Sektor yang mengalamai } \\
\text { Transformasi dari Non-Baisis } \\
\text { Menjadi Subsitem/sebaliknya }\end{array}$ & $\begin{array}{c}\text { Sektor yang } \\
\text { Mengalami } \\
\text { Transformasi dari } \\
\text { Basis menjadi Non } \\
\text { basis }\end{array}$ \\
\hline DKI JAKARTA & & $\begin{array}{l}\text { Reparasi Mobil dan Sepeda } \\
\text { Motor (dari Basis Menjadi Non- } \\
\text { Basis/Subsistem) }\end{array}$ & \\
\hline JAWA BARAT & $\begin{array}{l}\text { - Pengadaan Air, } \\
\text { Pengelolaan Sampah, } \\
\text { Limbah dan Daur } \\
\text { Ulang } \\
\text { - Transportasi dan } \\
\text { Pergudangan }\end{array}$ & & $\begin{array}{l}\text { Pertambangan dan } \\
\text { Penggalian }\end{array}$ \\
\hline JAWA TENGAH & $\begin{array}{l}\text { - Pertambangan dan } \\
\text { Penggalian } \\
\text { - Jasa Pendidikan }\end{array}$ & & $\begin{array}{l}\text { Pengadaan Air, } \\
\text { Pengelolaan Sampah, } \\
\text { Limbah dan Daur } \\
\text { Ulang }\end{array}$ \\
\hline DI YOGYAKARTA & $\begin{array}{l}\text { Perdagangan Besar dan } \\
\text { Eceran, }\end{array}$ & & \\
\hline JAWA TIMUR & & & $\begin{array}{l}\text { - Pengadaan Listrik } \\
\text { dan Gas } \\
\text { - Informasi dan } \\
\text { Komunikasi }\end{array}$ \\
\hline BANTEN & & $\begin{array}{l}\text { Kontruksi Perdagangan } \\
\text { dan Eceran (dari non basis } \\
\text { menjadi subsistem) }\end{array}$ & \\
\hline BALI & - & - & - \\
\hline
\end{tabular}

\section{Pembahasan}

Hasil temuan mengidentifikasikan bahwa secara umum perekonoman Jawa-Bali pada tahun 2010 dan 2019 tidak banyak mengalami pergeseran struktur ekonomi. Sektorsektor yang menjadi basis atau menjadi sumber pertumbuhan pada tahun 2010 di masingmasing provinsi di Jawa-Bali pada umumnya tidak mengalami perubahan. Hanya beberap sektor yang mengalami perubahan yaitu:

a. Sektor Reparasi Mobil dan Sepeda Motor di Provinsi DKI pada tahun 2010 masih menjadi sektor basis, namun pada tahun 2019 berubah menjadi sektor non-basis, meskipun secara koefisien nilai $\mathrm{LQ}=1$ yang berarti komoditas tergolong non-basis, tidak memiliki keunggulan komparatif, produksinya hanya cukup untuk memenuhi kebutuhan wilayah sendiri dan tidak mampu untuk diekspor. Untuk itu, ke depan sebaiknya Pemprov DKI memperhatikan kebijakan yang dapat mendorong sektor ini menjadi sektor yang memiliki keunggulan komparatif dan dapat diekspor ke luar. 
b. Provinsi Jawa Barat mampu mentransformasi sektor (a) Pengadaan Air, Pengelolaan Sampah, Limbah dan Daur Ulang, dan sektor (b) Transportasi dan Pergudangan, dari yang sebelumnya sektor non basis (2010) menjadi sektor basis pada tahun 2019. Dengan demikian, kedua sektor ini dapat menjadi sumber pertumbuhan, memiliki keunggulan komparatif, hasilnya tidak saja dapat memenuhi kebutuhan di wilayah yang bersangkutan, akan tetapi juga dapat diekspor ke luar wilayah perekonomin yang dapat menghasilkan nilai tambah ekonomi. Namun, dalam kurun waktu 2010 ke 2019, Provinsi Jabar juga mengalami penurunan peran pada sektor Pertambangan dan Penggalian. Pada tahun 2010, sektor ini masih menjadi sektor basis karena nilai LQ nya masih $>1(1,28)$ dan turun menjadi 0,81 pada tahun 2019. Dengan demikian, provinsi Jabar memerlukan impor untuk mencukupi kebutuhan sektor pertambangan dan penggalian. Pemprov Jabar perlu mensinergikan dengan kebijakan pemerintah Pusat agar ke depan sektor ini berkembang dan mampu Kembali menjadi sektor unggulan di Jawa Barat.

c. Provinsi Jawa Tengah juga mampu mentransformasi dua sektor, yaitu (a) Pertambangan dan Penggalian, dan sektor (b) Jasa Pendidikan, dari yang sebelumnya sektor non basis (2010) menjadi sektor basis pada tahun 2019. Dengan demikian, di tahun 2019 kedua sektor ini dapat memiliki keunggulan komparatif, dan sumber pertumbuhan, serta hasilnya tidak saja dapat memenuhi kebutuhan di wilayah yang bersangkutan, akan tetapi juga dapat diekspor ke luar wilayah perekonomin yang dapat menghasilkan nilai tambah ekonomi. Namun, dalam kurun waktu 2010 ke 2019, Provinsi Jateng juga mengalami penurunan peran pada sektor Pengadaan Air, Pengelolaan Sampah, Limbah dan Daur Ulang. Pada tahun 2010, sektor ini masih menjadi sektor basis karena nilai LQ nya masih $>1(1,01)$ dan turun menjadi 0,91 pada tahun 2019. Dengan demikian, provinsi Jateng memerlukan impor untuk mencukupi kebutuhan sektor Pengadaan Air, Pengelolaan Sampah, Limbah dan Daur Ulang. Ke depan Pemprov Jateng perlu terus mengupayakan sinergi dengan kebijakan pemerintah Pusat sehingga sektor-sektor yang bersifat basis akan terus menjadi sumber pertumbuhan dan sektor-sektor yang non basis dapat ditranform menjadi sektor basis.

d. Provinsi DIY mampu mentransformasi sektor Perdagangan Besar dan Eceran, dari yang sebelumnya sektor non basis (2010) menjadi sektor basis pada tahun 2019. Dengan demikian, kedua sektor ini dapat menjadi sumber pertumbuhan dan memiliki keunggulan komparatif. Disamping mempertahankan sektor-sektor yang sudah menjadi basis pertumbuhan, DIY perlu terus mengupayakan peningkatan kualitas kebijakan dan fokus pada sektor yang bersifat non basis (ada 6 sektor) sehingga sektor-sektor tersebut semakin berdaya saing dan mampu menjadi sumber pertumbuhan ekonomi.

e. Jawa Timur mengalami perubahan yang bersifat penurunan pada dua sektor yaitu: (a) Pengadaan Listrik dan Gas, dan (b) Informasi dan Komunikasi. Kedua sektor ini masih menjadi sektor basis pada tahun 2010, namun berubah menjadi sektor non basis pada tahun 2019. Dengan demikian, untuk mencukup kebutuhan permintaan domestic, Jawa Timur perlu mengimpor keduaa sektor tersebut dari luar. SInergi kebijakan di kedua sektor tersbut dengan kebijakan pemerintah pusat diperlukan akan kedua sektor tersebut dan sektor lain yang masih manjadi sektor basis dan semakin memberikan peran yang optimal dalam mendorong pertumbuhan ekonomi di provinsi Jatim. 
f. Provinsi Banten tidak banyak mengalamai perubahan dalam struktur ekonomi, hanya terjadi perubahan pada sektor Kontruksi Perdagangan Besar dan Eceran, dari yang sebelumnya sektor non-basis memerlukan impor dari luar menjadi sektor non-basis namun cukup untuk memenuhi kebutuhan domestic. Banten diharapkan fokus pada sektor basis agar sektor tersebut mampu menjadi semakin kompetetif, dan berupaya mendorong sektor-sektor non basis agar mampu tumbuh menjadi sektor basis dan memberikan kontribusi yang semakin tinggi terhadap pertumbuhan ekonomi.

g. Provinsi Bali tidak terjadi perubahan struktur ekonomi dari tahun 2010 ke tahun 2019. Bali diharapkan fokus pada sektor basis agar sektor tersebut mampu secara yterus menerus sebagai sumber pertumbuhan dan berupaya mendorong sektor-sektor non basis (8 sektor) agar mampu tumbuh menjadi sektor basis yang lebih kompetetif.

\section{Hasil analisis Shift Share dan Pembahasan.}

Sesuai dinamika pengelolaan pembangunan dari tahun ke tahun, sebuah sektor ekonomi bisa menjadi kurang penting peranannya dalam pembentukan PDB/PDRB digeser oleh sektor lainnya sesuai dengan kondisi ekonomi yang sedang terjadi saat itu. Untuk mengetahui pergeseran sektor-sektor ekonomi di suatu wilayah dapat dianalisis dengan metode shift share. Hasil analisis terhadap perhitungan (Sift Share Analisis) 7 provinsi di wilayah Jawa-Bali terlihat pada table-tabel berikut:

\section{a. Komponen Pertumbuhan Jawa-Bali (KPJB)}

Hasil perhitungan didapatkan bahwa nilai KPJB sebesar 0,66 yang berarti ekonomi (PDRB) Jawa-Bali dalam kurun waktu 2010 sd 2019 tumbuh sebesar 66\% (PDRB atas harga konstan 2010).

\section{b. Komponen Pertumbuhan Proporsional (KPP)}

KPP (proportionaly shift) merupakan alat untuk mengukur tingkat pertumbuhan produksi suatu wilayah lebih cepat atau lebih lambat dari pertumbuhan produksi nasional (dalam hal ini Jawa-Bali) karena tingginya konsentrasi industri (sektor) regional. Hasil perhitungan KPP di wilayah Jawa-Bali 2010 - 2019 terlihat dalam Table 5 berikut:

Tabel 5: KPP di wilayah Jawa-Bali 2010 - 2019

\begin{tabular}{|l|l|c|}
\hline NO. & \multicolumn{1}{|c|}{ SEKTOR } & KPP \\
\hline & & \\
\hline 1 & Pertanian, Kehutanan, dan Perikanan & -0.43 \\
\hline 2 & Pertambangan dan Penggalian & -0.34 \\
\hline 3 & Industri Pengolahan & -0.08 \\
\hline 4 & Pengadaan Listrik dan Gas & -0.46 \\
\hline 5 & Pengadaan Air, Pengelolaan Sampah, Limbah dan Daur Ulang & -0.20 \\
\hline 6 & Kontruksi & 0.01 \\
\hline 7 & Perdagangan Besar dan Eceran,Reparasi Mobil dan Sepeda Motor & 0.01 \\
\hline 8 & Transportasi dan Pergudangan & 0.25 \\
\hline
\end{tabular}




\begin{tabular}{|l|l|c|}
\hline 9 & Penyedia Akomodasi \& Makan Minum & 0.16 \\
\hline 10 & Informasi dan Komunikasi & 0.78 \\
\hline 11 & Jasa Keuangan dan Asuransi & 0.13 \\
\hline 12 & Real Estat & 0.03 \\
\hline 13 & Jasa Perusahaan & 0.41 \\
\hline 14 & Administrasi Pemerintahan, Pertahanan dan Jaminan Sosial Wajib & -0.35 \\
\hline 15 & Jasa Pendidikan & 0.16 \\
\hline 16 & Jasa Kesehatan dan Kegiatan Sosial & 0.32 \\
\hline 17 & Jasa Lainnya & 0.30 \\
\hline
\end{tabular}

Hasil perhitungan KPP memperlihatkan bahwa terdapat 6 sektor (Pertanian, Kehutanan, dan Perikanan; Pertambangan dan Penggalian; Industri Pengolahan; Pengadaan Listrik dan Gas; Pengadaan Air, Pengelolaan Sampah, Limbah dan Daur Ulang; dan Administrasi Pemerintahan, Pertahanan dan Jaminan Sosial Wajib) masing-masing sektor memiliki pertumbuhan yang lebih lambat dari pertumbuhan PDRB se Jawa-Bali. Sementara itu, 11 sektor lainnya masing-masing memiliki pertumbuhan yang lebih cepat dari pertumbuhan PDRB se Jawa-Bali pada kururn waktu 2010-2019. Implikasi dari temuan ini adalah kebijakan pembangunan wilayah Jawa-Bali perlu diarahkan untuk meningkatkan nilai tambah (value added) ke 6 sektor yang tumbuh lebih lambat dari pertumbuhan PDRB se wilayah Jawa-Bali.

\section{c. Komponen Pertumbuhan Pangsa Wilayah/KPPW}

KPPW (differential shift) mengukur daya saing suatu sektor di suatu provinsi dibandingkan dengan pertumbuhan sektor yang sama di provinsi lain. KPPW terjadi karena peningkatan atau penurunan output di suatu wilayah yang disebabkan oleh keunggulan komparatif, akses ke pasar input dan output, maupun infrastruktur ekonomi. Hasil perhitugan KPPW terlihat dalam Table 6.

Tabel 6. KPPW 7 Provinsi di Wilayah Jawa-Bali 2010 - 201

\begin{tabular}{|l|c|c|c|c|c|c|c|}
\hline \multirow{2}{*}{ Sektor } & \multicolumn{7}{|c|}{ KPPW/Differential Shift } \\
\cline { 2 - 8 } & $\begin{array}{c}\text { DSD } \\
\text { KI }\end{array}$ & $\begin{array}{c}\text { DSJa } \\
\text { bar }\end{array}$ & $\begin{array}{c}\text { DSJat } \\
\text { eng }\end{array}$ & $\begin{array}{c}\text { DSD } \\
\text { IY }\end{array}$ & $\begin{array}{c}\text { DSJa } \\
\text { tim }\end{array}$ & $\begin{array}{c}\text { DSBa } \\
\text { nten }\end{array}$ & $\begin{array}{c}\text { DSB } \\
\text { ali }\end{array}$ \\
\hline Pertanian, Kehutanan, dan Perikanan & -0.14 & -0.06 & 0.00 & -0.11 & 0.01 & 0.22 & 0.10 \\
\hline Pertambangan dan Penggalian & -0.34 & -0.50 & 0.30 & 0.05 & 0.23 & -0.22 & - \\
\hline Industri Pengolahan & -0.16 & 0.01 & 0.00 & -0.15 & 0.13 & -0.14 & 0.00 \\
\hline Pengadaan Listrik dan Gas & 0.58 & -0.19 & 0.50 & 0.54 & -0.19 & -0.13 & 0.56 \\
\hline $\begin{array}{l}\text { Pengadaan Air, Pengelolaan Sampah, Limbah } \\
\text { dan Daur Ulang }\end{array}$ & -0.07 & 0.20 & -0.20 & -0.11 & 0.01 & 0.07 & - \\
\hline Kontruksi & -0.22 & 0.33 & -0.07 & 0.17 & 0.04 & 0.45 & 0.29 \\
\hline
\end{tabular}




\begin{tabular}{|l|l|l|l|l|l|l|l|}
\hline $\begin{array}{l}\text { Perdagangan Besar dan Eceran,Reparasi } \\
\text { Mobil dan Sepeda Motor }\end{array}$ & -0.06 & -0.01 & -0.10 & 0.00 & 0.09 & 0.14 & 0.20 \\
\hline Transportasi dan Pergudangan & 0.31 & -0.01 & -0.04 & -0.41 & -0.12 & -0.11 & - \\
\hline & -0.13 & 0.07 & -0.04 & -0.04 & 0.13 & 0.03 & 0.01 \\
\hline Penyedia Akomodasi \& Makan Minum & 0.16 & 0.63 & -0.01 & -0.56 & -0.41 & -0.02 & - \\
\hline Informasi dan Komunikasi & 0.01 & 0.01 & -0.25 & 0.08 & 0.08 & 0.18 & 0.04 \\
\hline Jasa Keuangan dan Asuransi & -0.13 & 0.27 & 0.07 & -0.03 & 0.05 & 0.28 & - \\
\hline Real Estat & 0.05 \\
\hline Jasa Perusahaan & 0.05 & 0.05 & 0.16 & -0.38 & -0.39 & -0.12 & - \\
\hline $\begin{array}{l}\text { Administrasi Pemerintahan, Pertahanan dan } \\
\text { Jaminan Sosial Wajib }\end{array}$ & -0.04 & -0.09 & -0.04 & 0.25 & 0.01 & 0.32 & 0.41 \\
\hline Jasa Pendidikan & -0.29 & 0.52 & 0.56 & -0.14 & -0.06 & -0.11 & 0.18 \\
\hline Jasa Kesehatan dan Kegiatan Sosial & -0.12 & 0.35 & 0.15 & -0.19 & 0.10 & -0.30 & 0.13 \\
\hline Jasa Lainnya & 0.20 & 0.22 & -0.17 & -0.29 & -0.45 & -0.15 & \begin{tabular}{c}
0.11 \\
\hline
\end{tabular} \\
\hline
\end{tabular}

Dari perspektif perekonomian Jawa-Bali, hasil perhitungan KPPW memperlihatkan bahwa sektor-sektor di Provinsi Jabar dan Jatim mempunyai daya saing yang cukup baik (ada 11 sektor) disusul Bali (10 sektor), Banten (8 sektor), Jateng (7 sektor), DKI dan DIY masing-maisng 6 sektor yang memeiliki daya saing cukup baik. Definisi daya saing disini dimaknai sebagai daya saing masing-masing sektor di masing-masing provinsi terhadap daya saing total sektor yang sama se Jawa-Bali). Sektor industri pengolahan hanya kompetitif di 2 provinsi yaitu Jawa Barat dan Jatim. Sedangkan sektor industri pengolahan di Bali mempunyai daya saing yang sama dengan daya saing sektor tersebut secara keseluruhan (se wilayah Jawa Bali). Daya saing yang baik sektor Informasi dan komunikasi hanya dimiliki oleh 2 provinsi yaitu DKI dan Jabar. Daya saing yang baik untuk sektor transportasi dan pergudangan hanya dimiliki oleh provinsi Jabar. Implikasi dari hasil temuan ini adalah kesiapan provinsi-provinsi di wilayah Jawa-Bali dalam untuk melakukan transformasi ke sektor yang berbasis teknologi (industri pengolahan, informasi dan komunikasi) masih sangat rendah. Hampir semua provinsi mempunyai daya saing yang baik di bidang jasa keuangan dan asuransi (6 dari 7 provinsi yang diteliti). Hal ini memperkuat argumen bahwa sebagian besar wilayah di Jawa-Bali sedang menuju proses deindustrialiasi. Tingginya perkembangan kontribusi sektor tersier (jasa-jasa) terhadap PRDB Jawa-Bali diatas sektor sekunder (manufaktur, listrik, gas dan bangunan), diduga sektor jasa didominasi oleh sektor informal. Ini juga menunjukkan gejala terjadinya premature deindustrialisasi. Efek perlambatan industri manufaktur, yang pertama adalah penurunan penerimaan pajak, karena industri pengolahan menyumbang 30\% penerimaan pajak. Kedua, dengan deindustrialisasi prematur, potensi penciptaan lapangan kerja di sektor industri pengolahan menurun dan meningkatkan risiko pengangguran.

\section{d. Profil Perubahan Struktur Ekonomi 7 Provinsi di Wilayah Jawa-Bali}


Apabila hasil perhitungan shift share dipetakan dalam bentuk gafiik kuadran maka nampak posisi perubahan struktur ekonomi di 7 provinsi di wilayah Jawa-Bali sebagaimana Gambar 3 dibawah. Seperti terlihat dalam Gambar 3 bahwa sektor Industri pengolahan di Sebagian besar provinsi, posisinya berada di kuadran III yang berarti tumbuh lamban dan komoditasnya kurang mempunyai daya saing. Sementara, Industri komunikasi dan Informasi (10) sebagian besar berada pada kuadran II yang berarti sektor ini tumbuh secara progresif namun kurang mempunyai daya saing.

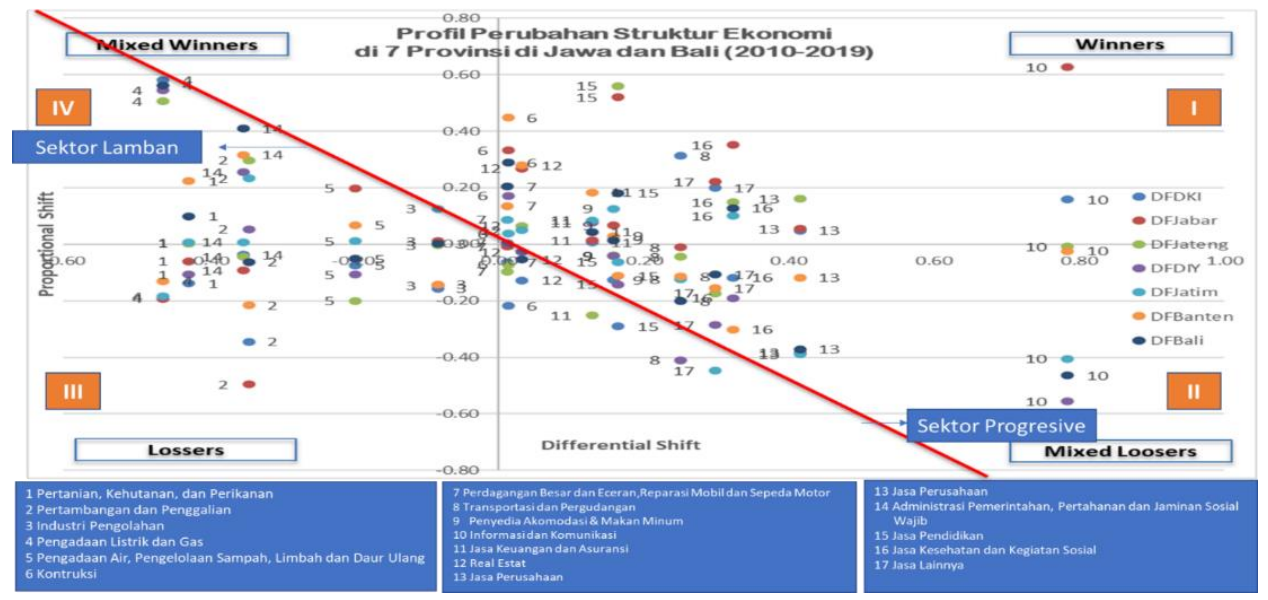

Gambar 3: Hasil Analisis Shift Share Profile Perubahan Struktur Ekonomi 7 Provibsi di

Wilayah Jawa-Bali 2020-2019

Begitu halnya dengan sektor transportasi dan pergudangan (8), di sebagian besar provinsi sebenarnya sektor ini tumbuh secara progresif, namun sektor transportasi dan pergudangan nampaknya kurang mempunyai daya saing yang baik (kuadran II). Sektorsektor jasa $(15,16,17)$ di sebagian besar provinsi telah tumbuh progresif dan mempunyai daya saing yang baik (kuadran I). Implikasi dari temuan ini adalah adanya gejala terjadinya premature deindustrialisasi. Deindustrialisasi yang premature di Jawa-Bali, berpotensi dalam penurunan penciptaan lapangan kerja di sektor industri pengolahan dan meningkatkan risiko pengangguran. Meskipun sektor jasa tumbuh progresif dan berdaya saing; namun, bila diperhatikan dari sisi produktivitas tenaga kerja, nampak bahwa produktivitas tenaga kerja sektor jasa ini jauh lebih kecil dibanding produktivitas tenaga kerja sector industri pengolahan (Haryanto, 2020). Ini berimplikasi bahwa sektor jasa banyak menyerap tenaga kerja yang dengan kualitas rendah dan diperkirakan akan cukup rentan terhadap dampak krisis.

\section{Kesimpulan dan Rekomendasi Kebijakan}

\section{Kesimpulan}

Hasil analisis LQ 7 provinsi di Jawa-Bali menunjukkan secara umum perekonoman Jawa-Bali pada tahun 2010 dan 2019 tidak banyak mengalami pergeseran struktur ekonomi. Sektor-sektor yang menjadi basis atau menjadi sumber pertumbuhan pada tahun 2010 di masing-masing provinsi di Jawa-Bali pada umumnya masih tetap menjadi sektor bais/sumnber pertumbuhan di tahun 2019. Beberapa sektor yang mengalami perubahan 
antara lain: Sektor Reparasi Mobil dan Sepeda Motor di Provinsi DKI berubah menjadi sektor non-basis tahun 2019, sektor (a) Pengadaan Air, Pengelolaan Sampah, Limbah dan Daur Ulang, dan sektor (b) Transportasi dan Pergudangan, dari yang sebelumnya sektor non basis (2010) di Jabar berubah menjadi sektor basis pada tahun 2019. Namun, sektor Pertambangan dan Penggalian, berubah menjadi sektor non-basis. Provinsi Jawa Tengah mampu mentransforn dua sektor menjadi sektor basis tahun 2019, yaitu (a) Pertambangan dan Penggalian, dan sektor (b) Jasa Pendidikan, dari yang sebelumnya sektor non basis (2010) menjadi sektor basis pada tahun 2019, namun satu sektor menurun menjadi non basis yaitu Pengadaan Air, Pengelolaan Sampah, Limbah dan Daur Ulang. Provinsi DIY mampu mentransform sektor Perdagangan Besar dan Eceran ke sektor Basis tahun 2019. Jawa Timur mengalami perubahan yang bersifat penurunan pada dua sektor yaitu: (a) Pengadaan Listrik dan Gas, dan (b) Informasi dan Komunikasi. Provinsi Banten tidak banyak mengalamai perubahan dalam struktur ekonomi, hanya terjadi perubahan pada sektor Kontruksi Perdagangan Besar dan Eceran, dari yang sebelumnya sektor non-basis memerlukan impor dari luar menjadi sektor non-basis namun cukup untuk memenuhi kebutuhan domestic.

Hasil analisis shift share memperlihatkan bahwa sektor industri pengolahan (3) di sebagian besar provinsi, posisinya berada di kuadran III yang berarti tumbuh lamban dan komoditasnya kurang mempunyai daya saing. Sementara itu, sektor industri komunikasi dan Informasi (10) sebagian besar berada pada kuadran II yang berarti sektor ini tumbuh secara progresif namun kurang mempunyai daya saing. Begitu juga dengan sektor transportasi dan pergudangan (8), di sebagian besar provinsi sektor ini mampu tumbuh secara progresif, namun sektor ini kurang mempunyai daya saing yang baik (kuadran II). Disisi lain, sektorsektor jasa $(15,16,17)$ di sebagian besar provinsi telah tumbuh progresif dan mempunyai daya saing yang baik (kuadran I). Implikasi dari temuan ini adalah adanya gejala terjadinya premature deindustrialisasi. Deindustrialisasi yang premature di Jawa-Bali, berpotensi dalam penurunan penciptaan lapangan kerja di sektor industri pengolahan dan meningkatkan risiko pengangguran. Meskipun sektor jasa tumbuh progresif dan berdaya saing; namun, bila diperhatikan dari sisi produktivitas tenaga kerja, nampak bahwa produktivitas tenaga kerja sektor jasa ini jauh lebih kecil dibanding produktivitas tenaga kerja sektor industri pengolahan (Haryanto, 2020). Ini berimplikasi bahwa sektor jasa banyak menyerap tenaga kerja dengan kualitas rendah dan produktifitas yang diperkirakan cukup rentan terhadap dampak krisis.

\section{Rekomendasi Kebijakan}

a. Peran strategis sektor industri sebagai mesin pembangunan ekonomi, bukan tanpa alasan, karena sektor industri akan membawa dampak turunan, yakni meningkatnya nilai kapitalisasi modal, kemampuan menyerap tenaga kerja yang besar, serta kemampuan menciptakan nilai tambah (value added creation) dari setiap input atau bahan dasar yang diolah. Sementara, sektor industri pengolahan se provinsi Jawa-Bali dalam krurun waktu 2010-2019 memiliki pertumbuhan yang kurang progresif dan daya saing yang kurang baik. Untuk itu, dalam jangka pendek, kebijakan ekonomi Jawa-Bali harus secara serempak diarahkan untuk pengembangan industri pengolahan yang berbasis sumber daya alam secara masif di seluruh sentra produksi seperti pertambangan, perikanan, perkebunan, 
pertanian dan lainnya. Industri pengolahan harus mampu memberi nilai tambah (value added) pada produk-produk sektor primer. Sejalan dengan itu, hilirisasi subsektor industri manufaktur yang memiliki keterkaitan kuat ke depan patut dijadikan prioritas. Lesson learn dari sukses transformasi ekonomi pada beberapa negara maju, membuktikan peranan sektor industri yang lebih dominan dibandingkan dengan sektor lainnya, sektor industri memegang peran kunci sebagai mesin pembangunan ekonominya.

b. Reformulasi kebijakan pembangunan wilayah Jawa-Bali dengan mengarusutamakan tansformasi struktur sektor industri pengolahan, informasi dan teknologi sebagai pilar utama pembangunan. Mainstraiming pembangunan di bidang jasa, seperti sektor pariwisata cenderung mendorong efek berkembangnya jasa-jasa yang bersifat informal dan dapat memperdalam fenomena premature deindustrialisasi yang dapat menyebabkan kerentanan stabilitas makroekonomi, mengingat sektor manufaktur dalam negeri belum mature/mapan.

c. Sektor informasi dan teknologi di sebagian besar provinsi di wilayah Jawa-Bali mempunyai pertumbuhan yang sangat progresif, namun kurang didukung dengan daya saing yang baik pada sektor ini, Hal ini nampak pada posisi pemetaan hasil analisis Shift Share yang sebgaian besar berada pada Kuadran II. Untuk itu, pengembangan kapasitas SDM yang terstruktur dan sisitematis, berbasis pada Inovasi dan penguasaan ilmu pengetahuan teknologi dan informasi perlu mendapatkan prioritas tinggi. Disamping itu, penguatan lembaga-lembaga riset yang berbasis pada inovasi sektor industri, berdampak signifikan pada sektor produksi, dan mampu memberikan peningkatan nilai tambah (added value), perlu dilakukan oleh pemerintah, sehingga hasil riset terkoneksi langsung dengan kebijakan transformasi struktural.

d. Pengembangan Pusat-Pusat Ilmu Pengetahuan dan Teknologi Informasi di Kawasan-Kawasan Ekonomi/Industri Khusus di wilayah Jawa-Bali sebagai pusatpusat inovasi, riset pengembangan produk, inkubasi bisnis, alih teknologi, sertifikasi, mediasi dan promosi untuk mendukung daya saing sektor industri manufaktur, informasi dan teknologi.

e. Transformasi ekonomi sektor industri, dan pengembangan sektor informasi dan teknologi di wilayah Jawa-Bali tidak akan berhasil tanpa didukung iklim investasi yang kondusif. Sementara, fakta menunjukkan bahwa investasi asing cenderung tersendat masuk ke sektor riil, karena begitu banyaknya hambatan-hambatan yang belum bisa teratasi sampai saat ini, mulai dari perizinan (regulasi), infrastruktur, birokrasi, pengadaan lahan, kondisi ketenagakerjaan, dangkal dan rigidnya sektor keuangan, dan sebagainya. Belum teratasinya hambatanhambatan tersebut tercermin dari posisi daya saing ekonomi Indonesia yang masih tertinggal dari negara tetangga, Untuk itu, Indonesia harus secara konsisten dan terpola (dalam mengawal implementasi Omnibus Law) sebagai langka dalam melakukan reformasi dibidang kelembagaan/regulasi, investasi, birokrasi, ketenagkerjaan, infrastruktur, pertanahan dan sektor keuangan.

f. Perlu kajian lebih lanjut dengan mempertajam sub analisis pada level sub sektor atau komoditias, agar rekomendasi kebijakan lebih terfokus dan lebih operasional. 


\section{Daftar Pustaka}

Arsyad, L. (1999) Pengantar Perencanaan dan Pembangunan Ekonomi Daerah,. Edisi Pertama, BPFE, Yogyakarta.

BPS Provinsi Banten, (2021) Statistik Ekonomi dan Perdagangan. Available at: https://banten.bps.go.id/subject/52/pdrb-menurut-lapanganusaha.html\#subjekViewTab5

BPS Provinsi DIY, (2021) Statistik Ekonomi dan Perdagangan. Available at: https://yogyakarta.bps.go.id/subject/52/pdrb-menurut-lapanganusaha.html\#subjekViewTab5

BPS Provinsi Jabar, (2021) Statistik Ekonomi dan Perdagangan. Available at: https://jabar.bps.go.id/subject/52/pdrb-menurut-lapanganusaha.html\#subjekViewTab5

BPS Provinsi DKI, (2021) Statistik Ekonomi dan Perdagangan. Available at: https://jakarta.bps.go.id/subject/52/pdrb-menurut-lapanganusaha.html\#subjekViewTab5

BPS Provinsi Jatim, (2021) Statistik Ekonomi dan Perdagangan. Available at: https://jatim.bps.go.id/subject/52/pdrb-menurut-lapanganusaha.html\#subjekViewTab5

BPS Provinsi Jateng, (2021) Statistik Ekonomi dan Perdagangan. Available at: https://jateng.bps.go.id/subject/52/pdrb-menurut-lapanganusaha.html\#subjekViewTab5

Glasson. 1977. Pengantar Perencanaan Regional. LPFE UI. Jakarta.

Goschin, Z. 2014. Regional growth in Romania after its accession to EU: a Shift-Share analysis approach. Procedia economic and finance. Available online in www.scientdirect.com. p. 169-175.

Haryanto (2020), Transformasi Struktural di Indonesia: Kerangka Konseptual, Teori, Tren, dan Temuan Empiris, Makalah Kebijakan.

Hood, Ron. 1998. Economic Analysis: A Location Quotient. Primer. Principal Sun Region Associates, Inc

Miller. M.1991. Location Quotient Basic Tool for Economic Development Analysis. Economic Development Review, 9(2);65.

Perloff, H. S. et al., Regions, Resources and Economic Growth (Johns Hopkins, 1960).

Rice, P. F and J. H. Marshall. 2010. Analysis Of Recent Changes In Arkansas Personal Income: 2007 - 2009: A Shift-Share Approach. Journal Of Business Administration Online 9(2): 1-12.

Soepono, Prasetyo. 1993. Analisis Shift-share : Perkembangan dan Penerapan. Jurnal Ekonomi dan Bisnis Indonesia, volume 8 nomor 1. Yogyakarta. Fakultas Ekonomi UGM

Tarigan, R. 2005. Perencanaan Pembangunan Wilayah. Edisi Revisi. PT. Bumi Aksara: Jakarta 